\title{
WORKING paper

\section{Flight-to-safety and the Credit Crunch: A new history of the banking crisis in France during the Great Depression}

\author{
Patrice Baubeau, ${ }^{1}$ Eric Monnet, ${ }^{2}$ Angelo Riva ${ }^{3}$ and \\ Stefano Ungaro ${ }^{4}$
}

\author{
November 2018, WP \#698
}

\begin{abstract}
Despite France's importance in the interwar world economy, the scale and consequences of the French banking crises of 1930-1931 were never assessed quantitatively due to lack of data in the absence of banking regulation. Using a new dataset of individual balance sheets from more than 400 banks, we show that the crisis was more severe and occurred earlier than previously thought, and it was very asymmetric, without affecting main commercial banks. The primary transmission channel was a flight-to-safety of deposits from banks to savings institutions and the central bank, leading to a major, persistent disruption in business lending. In line with the gold standard mentality, cash deposited with savings institutions and the central bank was used to decrease marketable public debt and increase gold reserves, rather than pursue countercyclical policies. Despite massive capital inflows, France suffered from a severe, persistent credit crunch.
\end{abstract}

Keywords: Great Depression, flight-to-safety, France, banking panics, Savings Banks, gold standard

JEL classification: N14, N24, G01, G21, G23, G33, E44, E51, E58

${ }^{1}$ University Paris Nanterre, IDHES (UMR 8533)

2 Bank of France, CEPR and PSE. Corresponding author: eric.monnet@banque-france.fr

${ }^{3}$ EBS Paris and PSE

${ }^{4}$ EHESS and PSE

This study was financed by the ANR (Agence Nationale pour la Recherche) under project name SYSRI 30 (ANR-15-CE26-0008). Édouard Vilpoux, François Chounet, and Federico D'Onofrio provided extensive research assistance, with additional assistance from Loukman Konaté, Alix Myczkowski, Étienne de L'Estoile, Sofiane Bouarif, Victor Degorce, and Jean-Laurent Cadorel. We are grateful to archivists Anne Brunterc'h, Pascal Penot (CASA), Frederik Grelard, and Fabrice Reuzé (Banque de France) for their help and time. This paper benefited greatly from comments from Pierre-Cyrille Hautcoeur, Gilles Postel-Vinay, Pierre Sicsic, Eugene White, Michael Bordo, Kaspar Zimmermann, Kris Mitchener, Sofiane Bouarif, Michele Fratianni, Leslie Hannah, Gary Richardson, Patrick Van Horn, Guillaume Vuillemey, and seminar participants at the Paris School of Economics, Banque de France, Saint Louis Fed, London School of Economics, WEHC in Boston, and BHC in Baltimore.

Working Papers reflect the opinions of the authors and do not necessarily express the views of the Banque de France. This document is available on publications.banque-france.fr/en 


\section{NON-TECHNICAL SUMMARY}

Previous research has downplayed the role of banking panics and financial factors in the French Great Depression of the 1930s. Although scholars acknowledged that some banking failures occurred in France during the period 1930-1932, the common view of the absence of significant economic consequences has persisted. It results from the lack of statistics able to provide a comprehensive picture of the magnitude of banking panics, in the absence of banking regulation in France prior to 1941. The usual method to compute series of bank credit and deposits relied on the balance sheet of the four largest commercial banks - whose data were easily available - and to assume that those banks represented half of the banking sector. These large banks did not experience difficulties and their deposits did not decrease in 1930 and 1931.

Based on extensive archival research we have found the balance sheets of more than 400 hundred banks in interwar France. This finding gives a completely different view of the 1930-1931 banking crises. Whereas the four large commercial banks escaped the crisis, the remainder of the banking system experienced two dramatic waves of panic (end of 1930 and end of 1931), such that its deposits decreased by 40\% between 1929 and 1931. The decrease in credit was even stronger (-44\%). Banking panics were concentrated in 1930-1931. The decrease of banking activity that followed starting 1932 is fully explained by deflation.

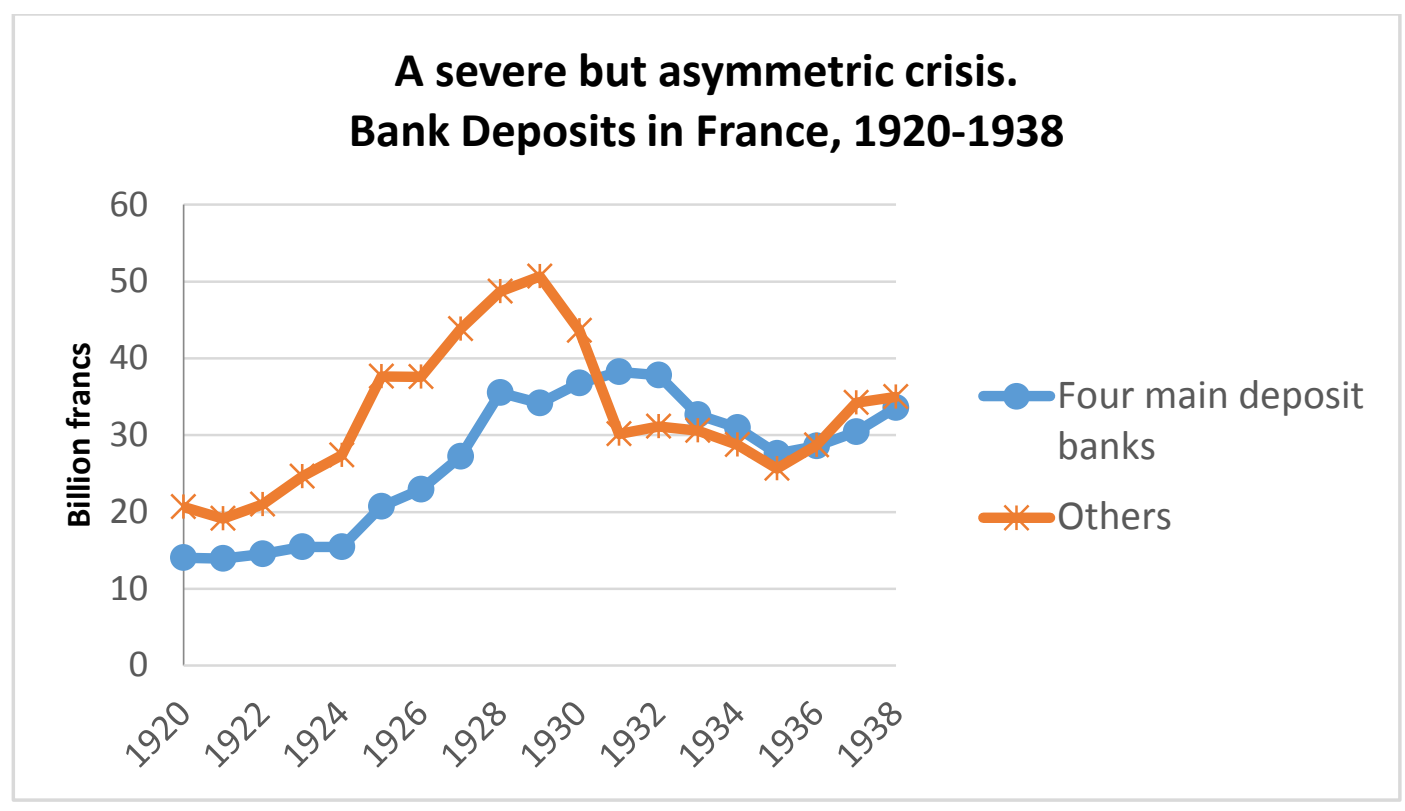

Banking theory explains the mechanisms of bank runs, but it is silent on where deposits go when they are withdrawn from the banking system. Traditional monetary interpretations point to a drop in the money multiplier and in the money base, either because cash is hoarded or because deposits remain frozen in bankrupt banks. Our estimation of hoarded cash and frozen deposits show that they cannot account for the bulk of deposits that fled the banking system in 1930 and 1931. Instead, most of these deposits went to savings institutions (Caisses d'Epargne) which collected deposits at a regulated interest rate and invested their assets in Treasury bonds. We characterize this phenomenon as a flight-to-safety. Because of capital inflows and the flight-to-safety from banks to non-banks, the total amount of deposits slightly increased in France from 1930 
to 1932. How can a country experience deflation and a decline of about $1 / 3$ in real activity, whereas at the same time the money supply increases? The answer to this question lies in the dramatic decrease of credit. A credit crunch occurred because the institutions that received deposits during the banking panic - namely the saving institutions and the central bank - did not lend to the economy. New cash deposited with the savings institutions (Caisses d'épargne) was used directly to repay marketable public debt, which decreased between 1928 and 1933. The large banks which were not affected by the crisis deposited $25 \%$ of their assets with the central bank. The central bank increased very modestly its lending to the economy (both banks and non-banks) but it was dwarfed by the dramatic increase in gold reserves, the ultimate safe asset. Gold reserves doubled between 1929 and 1932. No financial institution replaced the banking system as a lender to the economy.

\title{
Fuite vers la sécurité et effondrement du crédit. Une nouvelle histoire de la crise bancaire en France pendant la Grande Dépression
}

\begin{abstract}
Malgré l'importance de la France dans l'économie mondiale de l'entre-deux-guerres, l'ampleur et les conséquences des crises bancaires françaises des années 1930-1931 n'ont jamais été évaluées quantitativement en raison du manque de données, causé par l'absence de réglementation bancaire avant 1941. En utilisant de nouvelles données sur les bilans individuels de plus de 400 banques, nous montrons que la crise a été bien plus grave et s'est produite plus tôt que ce que les études précédentes indiquaient, et qu'elle fut très asymétrique, sans affecter les quatre grandes banques commerciales. Le principal canal de transmission a été la fuite des dépôts bancaires vers les caisses d'épargne et la banque centrale, ce qui a entrainé un effondrement important et persistant du crédit aux entreprises. Conformément à la mentalité de l'étalon-or, les liquidités déposées auprès des institutions d'épargne et de la banque centrale ont servi à réduire la dette publique négociable et à accroitre les réserves d'or, plutôt que de poursuivre des politiques contracycliques. Malgré des entrées massives de capitaux, la France a souffert d'un grave et persistant resserrement du crédit.
\end{abstract}

Mots-clés : Grande Dépression, fuite vers la sécurité, paniques bancaires, caisses d'épargne, étalon or, masse monétaire, système bancaire français

Les Documents de travail reflètent les idées personnelles de leurs auteurs et n'expriment pas nécessairement la position de la Banque de France. Ce document est disponible sur publications.banque-france.fr 
Despite the importance of the French economy and the international role its central bank played during the interwar period (Kindleberger 1986, Mouré 1991, Eichengreen 1992, Johnson 1998, Irwin 2010), a comprehensive, precise picture of the French banking crisis during the Great Depression is lacking due to the absence of data; French banks went unregulated until 1941, and there was no legal definition of banks and no supervisor that collected bank statistics. Relying on scattered sources, researchers have found that some banks failed during several panics, but they could neither assess their macroeconomic importance nor construct a detailed chronology of the crises (Bouvier 1984, Plessis 1991, Bonin 2000, Lescure 2004, Straus 2004).

There exists no exhaustive, historical quantitative research on the French banking system before 1945 equivalent to that from Hoffman, Postel-Vinay, and Rosenthal (2000, 2019) on notarial credit during the $19^{\text {th }}$ century. Quantitative studies use French monetary and banking credit statistics extrapolated from the balance sheets of the four (or six) largest commercial banks, the only ones easily accessible (INSEE 1952, Bouvier 1984, Saint Marc 1983, Patat \& Lutfalla 1986, Bernanke \& James 1991, Jonker and Van Zanden 1995, Mitchell 1998, Schularick \& Taylor 2012, Bridji 2013, Fratianni \& Giri 2017). The deposits of these banks-assumed to constantly represent half of the total banking system-were stable between 1929 and 1932, and thus it is commonly accepted that French bank failures were limited in size and had few consequences to total credit and money such that most authors even forbid themselves from speaking of a banking crisis. Kindleberger (1986, p.134) argues, "French banks escaped the difficulties of the rest of the continent." According to Feinstein, Temin, and Toniolo (1995, p.40), "French banks were generally in a strong position at the end of the 1920s and largely avoided the 1929-31 crisis." ${ }^{1}$ Since international literature does not

\footnotetext{
${ }^{1}$ In cross-country investigations, Bernanke and James (1991), Grossman (1994), and Eichengreen (2004) include France in countries that experienced banking panic during the Great Depression, but also consider this choice controversial, citing Bouvier (1984). In their widely used, recent datasets of historical banking crises, Reinhart
} 
consider major banking problems in France during 1930-1931, the difficulties of French banks are assumed to have occurred later than in other countries, and to be mere consequences of France's obstinate and deflationary adherence to the gold standard until 1936, rather than the result of banking panics (Grossman 1994, Eichengreen 2004, James 2009). ${ }^{2}$

We provide a revisionist account of this common view based on a new, comprehensive dataset of individual annual balance sheets of over four hundred banks during the interwar period (404 banks appear in our dataset between 1920 and 1938, with a maximum of 250 in 1928). France experienced two banking crises - a major panic from October 1930 to spring 1931, and a second, slightly more modest one during the second half of 1931 . Between the end of 1929 and the end of 1931, the number of banks in the dataset decreased by $30 \%$ while total deposits in the banking system declined by nearly a quarter. However, the crisis was asymmetrical; the four main commercial banks did not suffer from the crisis, but the remainder of the banking system lost $40 \%$ of deposits. The decrease in banking activity due to banking panics was concentrated during 1930-1931. In real terms, deposits and credit in the banking system in 1936 were equal to their level at the end of 1931. For comparison, researchers of the Great Depression in the United States would not have assessed the influence of banking panics if their research had been based on statistics from major New York banks that experienced little distress during the nationwide banking panics of 19301931 (Friedman and Schwartz 1963, Richardson and Mitchener 2016).

We provide detailed analyses of the transmission mechanisms of the crises, which have broader implications for international literature on the Great Depression and banking panics in

and Rogoff (2009) code a banking crisis dummy 1 for 1930, 1931, and 1932, and Schularick and Taylor (2012) code a dummy 1 for 1930 only. These disagreements are evidence of a lack of knowledge on the topic.

${ }^{2}$ The argument for a late banking crisis in France is often based on the most important liquidation of a bankthe Banque Nationale du Crédit (BNC) - in 1932. Overlooked, however, is that the liquidation started in January 1932 and was a direct consequence of troubles during 1931. The BNC experienced trouble in September 1931 and was bailed out by the government in October. Consequently, the 1932 liquidation and reorganization of the BNC into a new bank - Banque nationale pour le commerce et l'industrie (BNCI) — did not incur significant losses for depositors (Bonin 2002) and had no direct consequences on money and credit. 
history. The objective is to assess if — and if so, why—banking panics led to a major credit crunch. We document a monetary effect of the Great Depression, similar to Friedman and Schwartz (1963) for the United States - a drop in the money multiplier and money base unleashed by frozen deposits due to bank failures, individual hoarding of cash, and an increase in deposits of large commercial banks and private customers with the central bank. Quantitatively, the primary channel that led from bank distress to a credit crunch was a flightto-safety: depositors transferred their deposits from the banking system to state-guaranteed savings institutions, the Caisses d'épargne, which in turn financed the Treasury. ${ }^{3}$ Some deposits, notably those generated by capital inflows, also went to large, unstressed commercial banks, which deposited their money in the central bank (up to $25 \%$ of assets in 1931). During 1931, deposits withdrawn from the banking industry were as important as the net inflows of international capital. Quantitative analysis suggests that the sum of deposits that exited the banking system and foreign capital flowing into France were absorbed largely by the Caisses d'épargne (50\%), with the remainder hoarded in cash $(25 \%)$, deposited in the central bank (17\%), and frozen in bankrupt banks (only $8 \%$ ).

The French Treasury used cash deposited in the Caisses d'épargne to reduce marketable government debt, and the Banque de France increased its lending very modestly to the private economy and devoted the bulk of its excess money to build gold reserves (Mouré 1991). Thus, a credit crunch occurred because the institutions that eventually received funds (i.e., Caisses d'épargne and the central bank) did not lend those funds to private companies. The ratio of total loans to nonfinancial corporations on total deposits decreased from $40 \%$ to $20 \%$ between 1929 and 1931, and it began to recover only during 1936. This flight-to-safety channel is different from Bernanke's (1983) well-known argument about the U.S. Great Depression. Bernanke (1983) describes an amplification mechanism in which bank failures

\footnotetext{
${ }^{3}$ Either directly by purchasing government securities or indirectly by depositing cash at the Caisse des dépôts et consignations (CDC), which operated as a debtor current account in favor of the Treasury.
} 
led to nonmonetary effects because the cost of intermediation increased and some borrowers experienced costs that were too high. ${ }^{4}$ Our argument is closer to Mitchener and Richardson's (2016), who highlight the role of interbank deposits during U.S. banking panics; deposits moved from distressed banks in less developed areas of the country to safer banks in central reserve cities such as New York and Chicago, and those reserve banks decreased corporate loans and increased government loans and central bank deposits. Economic literature on flight-to-safety (Caballero \& Krishnamurthy 2008, Krishnamurthy 2010, Baele et al. 2013) focuses on a shift of assets by financial institutions. In contrast, most flights-to-safety came from depositors during the French Great Depression. This new interpretation leads to a different narrative from the prevailing one that emphasizes a drop in the money multiplier and a rise in information asymmetry as transmission mechanisms of banking crises during the Great Depression (see Mitchener and Richardson [2016] and Fratianni and Giri [2017] for recent summaries). The case of France during the 1930s is particularly striking because the credit crunch occurred during capital inflows caused by Poincaré monetary stabilization, then by the banking crises in Eastern Europe and finally by the devaluation of sterling during 1931 (Eichengreen 1992, Sicsic 1993, Johnson 1998, James 2009). Thus, the French crisis was not a balance of payment crises; the banking panics occurred simultaneously as massive capital inflows that should have had a positive effect on money creation. The first French banking panic in autumn 1930 even predated the international contagion crisis that began in Eastern Europe during spring 1931.

France's long-standing adherence to the gold standard until 1936 was not the primary cause of banking panics, but this does not mean that the gold standard did not play a role. Had French governments used Caisses d'épargne's deposits to pursue countercyclical,

\footnotetext{
${ }^{4}$ Bridji (2013) simulates a general equilibrium model of the French Great Depression and identifies a role for financial frictions, like that from Bernanke. However, his simulations are based on the flawed monetary statistics described above. From a different perspective, Lescure (2016) argues that information asymmetries were essential to the French crisis, caused by the tradition of discounting short-term paper, which prevented banks from establishing long-term relationships with customers.
} 
macroeconomic policies, and had the French central bank used its growing liability to support the private economy either directly or by refinancing banks and lending institutions, the magnitude of the credit crunch could have been mitigated. Hence, these deflationist policies cannot be understood outside a gold standard mentality (Mouré 1991, Eichengreen \& Temin 2000), which was accompanied by a fierce belief in the real bills doctrine that led Banque de France's officials to consider a decrease in discounting as a mere symptom of the decline of real activity, or even a welcome sign of decreased speculation, rather than the consequence of a disruption of financial intermediation. ${ }^{5}$ Extant studies discuss accumulation of gold reserves by the Banque de France and its deflationary influence on the international system (Nurkse 1944, Mouré 1991, Eichengreen 1992, Johnson 1998, Accominotti 2009, Irwin 2010) but do not address whether the policy made sense in the context of domestic French banking crises. ${ }^{6}$

\footnotetext{
${ }^{5}$ See Meltzer (2003, p. 411-13) for a similar conclusion on the U.S. Federal Reserve. For a discussion of the influence of the real bills doctrine on Banque de France's thinking, see Baubeau (2011).

${ }^{6}$ The Treasury and the Banque de France participated in the rescue of two major banks, and the central bank increased its liquidity moderately during the crises (Bouvier 1984, Hautcoeur 1990), but these reactions appear extremely Malthusian given the influence of these crises and the fall in credit creation that followed.
} 
When dealing with France, international studies of banking panics during the Great Depression written since the mid-1980s rely on Bouvier (1984), who acknowledges the failures of hundreds of small, private bank but denies the seriousness of the crisis because the largest banks were unaffected. Following Bouvier, subsequent literature suggests no banking crisis in France between 1929 and 1931, and total deposits were unaffected by bank failures (Villa, 1994). Official, aggregate French statistics of bankruptcies by sector are of little use to assess the magnitude and transmission channels of the crisis. In the absence of banking regulation, there was no legal definition of a bank. Many banks that appeared in bankruptcy statistics (under the moniker bankers or financiers) were securities houses, private discounters, or broker-dealers rather than institutions that took deposits and lent money (Lescure 2004). Such statistics do not inform the size and composition of failing companies' balance sheets.

Some French historians, especially Bonin (2000, 2002), Lescure (2004), and Straus (2004), offered a different perspective, showing that a large number of failures occurred among important regional banks. Nevertheless, they do not remove ambiguity regarding the overall importance of the French banking crises during the Great Depression. ${ }^{7}$ Using case studies, these authors identify two series of banking panic. One started in October 1930 with problems of the Banque Oustric and Banque Adam, and continued at least until February 1931. The second began during summer 1931 (the starting date is imprecise) and lasted to spring 1932 until completion of the bail out of the Banque Nationale du Crédit. Several bankruptcies occurred later until 1935 but were unassociated with wider panics. Thus, the

\footnotetext{
${ }^{7}$ Lacoue-Labarthe (2005) surveys this literature. Like Levy-Leboyer (1995) and Plessis (1996), he suggests that the number of bank failures should encourage historians to reopen the archives and reinvestigate the common view of the French Great Depression. The present paper does the same.
} 
macroeconomic picture of the crisis remains highly imprecise, including the chronology of a double domestic crisis.

Due to the absence of comprehensive data on bank balance sheets, series of deposits have been reconstructed retrospectively based on statistics from only a few large banks. Saint Marc (1983) and Mitchell (1998) use a retrospective series published by INSEE (1952), which multiplies by two the amount of deposits held by the four major commercial banks (i.e., Crédit Lyonnais, Société Générale, Comptoir d'escompte, and Crédit industriel et commercial) to approximate total deposits. Researchers have used such series of deposits and money supplies commonly ever since. Some alternatively use statistics from the League of Nations, which published data for six banks, the 4 main commercial banks, and 2 merchant banks (i.e., Crédit Commercial de France and Banque de Paris et des Pays Bas). ${ }^{8}$ These series suggest that large banks did not experience a crisis, but do not address the remainder of the banking system. In addition to a lack of official statistics, a fundamental, political economy explains lack of knowledge on the French banking crisis. Surviving, oligopolistic big banks constructed and publicized a powerful narrative, according to which the French banking troubles of the early 1930s had not been detrimental to the French economy and had only affected black sheep, immoral, and unsound bankers. This narrative was especially influential during parliamentary debates of 1936 regarding the opportunity of implementing banking regulations (Andrieu 1991, Mouré 1991, p.36-38).

\footnotetext{
${ }^{8}$ Only Patat and Lutfalla (1986) attempt more complex estimation, but they use only a few data points, without quoting sources. A series from Patat and Lutfalla begins in 1919 and thus is much less used in the literature than the series from Saint Marc, which spans 2 centuries. We argue that Patat and Lutfalla used data from Laufenburger (1940), which they do not quote and were based on aggregate statistics from the Crédit Lyonnais that we describe below, since Laufenburger's book has been partly prepared by economists from Crédit Lyonnais. Laufenburger published data for 1921, 1926, 1929, 1931, and 1933. Patat and Lutfalla derive figures for missing years using statistics from the four large banks. Aggregate series of deposits in the banking system published in Laufenburger (1940), and originally created by Crédit Lyonnais, summed total deposits of the Album without considering bankrupted banks whose assets were thus frozen (see below).
} 


\section{Reconstructing bank balance sheets: the Album}

This article is based on the discovery of a new source for studying the balance sheets of a large number of banks from 1901 to 1938 , thus exceeding the limits of the studies described above. This source - called the Album - was found in the archives of the Crédit Lyonnais.

\section{Sources of the Crédit Lyonnais}

Since the beginning of the $20^{\text {th }}$ century, Crédit Lyonnais, the largest French bank, has been collecting and standardizing annual bank balance sheets following a homogeneous definition. It defines banks as limited-liability companies that receive deposits and discounted commercial papers. It excludes brokers, individual financiers, real estate and insurance companies, public credit institutions (e.g., Crédit National and Caisse des Dépôts et Consignations), and state-regulated savings institutions (e.g., Caisses d'Epargne), but includes most investment banks and the largest cooperative banks (e.g., Banques Populaires and Crédit Agricole). ${ }^{9}$ It collected such information from 1901 to 1939 , based on annual reports that limited-liability companies were required to send to shareholders. The balance sheets were then standardized and recorded in a massive ledger-the Album. ${ }^{10}$ Crédit Lyonnais also collected information on bankruptcies. The Album was lost in the archives for more than half a century. When the Second World War began, information about 1939 remained incomplete, so the Album can be used only until 1938. Since the law of 1941 organized state supervision of banks, data collection never resumed and was forgotten. ${ }^{11}$

In interwar France, there was no standardized accounting framework for corporations (Praquin 2010, 2012). Before banking laws of 1941, neither the central bank nor the Treasury

\footnotetext{
${ }^{9}$ Until 1926, it also included banks of issues (i.e., Banque de France and colonial central banks) and the Crédit Foncier. They were excluded from present analyses.

${ }^{10}$ Available in the archives of the Crédit Agricole SA (CASA), which hosts Crédit Lyonnais archives.

${ }^{11}$ The only reference to this source is Laufenburger (1940), who had access to statistics of Crédit Lyonnais, though he did not explain precisely the origin and nature of the aggregated statistics he published. Lescure (2004) also reproduced some aggregate figures found in the archives of the Crédit Lyonnais (for deposits in 1929, 1931, 1936), without mentioning the Album.
} 
required banks to publish standardized balance sheets. Banque de France gathered regular information on the balance sheets of only the four main commercial banks. ${ }^{12}$ The Banque collected some information (e.g., capital and reserves) on its counterparties when making loans to banks but did not construct a standardized accounting framework to collect and register balance sheets. It focused on risk management of its portfolio but did not have a systemic approach to financial stability and banking statistics it would acquire after 1945 (Baubeau 2004, Monnet 2018). In this context, the work conducted by Crédit Lyonnais to collect and standardize balance sheets was an enormous undertaking. Crédit Lyonnais was able to construct the Album because since the late $19^{\text {th }}$ century, it had developed a strategy of banking development and risk assessment through detailed knowledge of accounting practices of nonfinancial and financial firms (Desjardins et al. 2003, Praquin 2005, 2010). Its central position in the French banking system allowed it to operationalize this strategy. Due to the heterogeneity of the balance sheets, it is likely that Crédit Lyonnais asked banks directly for additional information to perform standardization. Each time a bank was withdrawn from the Album, we have detailed information on the reasons it exited (e.g., bankruptcies, mergers and acquisition, etc.). In some cases of very small banks, the reason was that the bank no longer published a balance sheet, discounted commercial paper, or took deposits. This meant the bank had either reduced its activity considerably without being bankrupt or shifted its activities (see "other withdrawn" in Figure 1).

\footnotetext{
${ }^{12}$ Banque de France archives (BFA), 1069201116/48-71.
} 


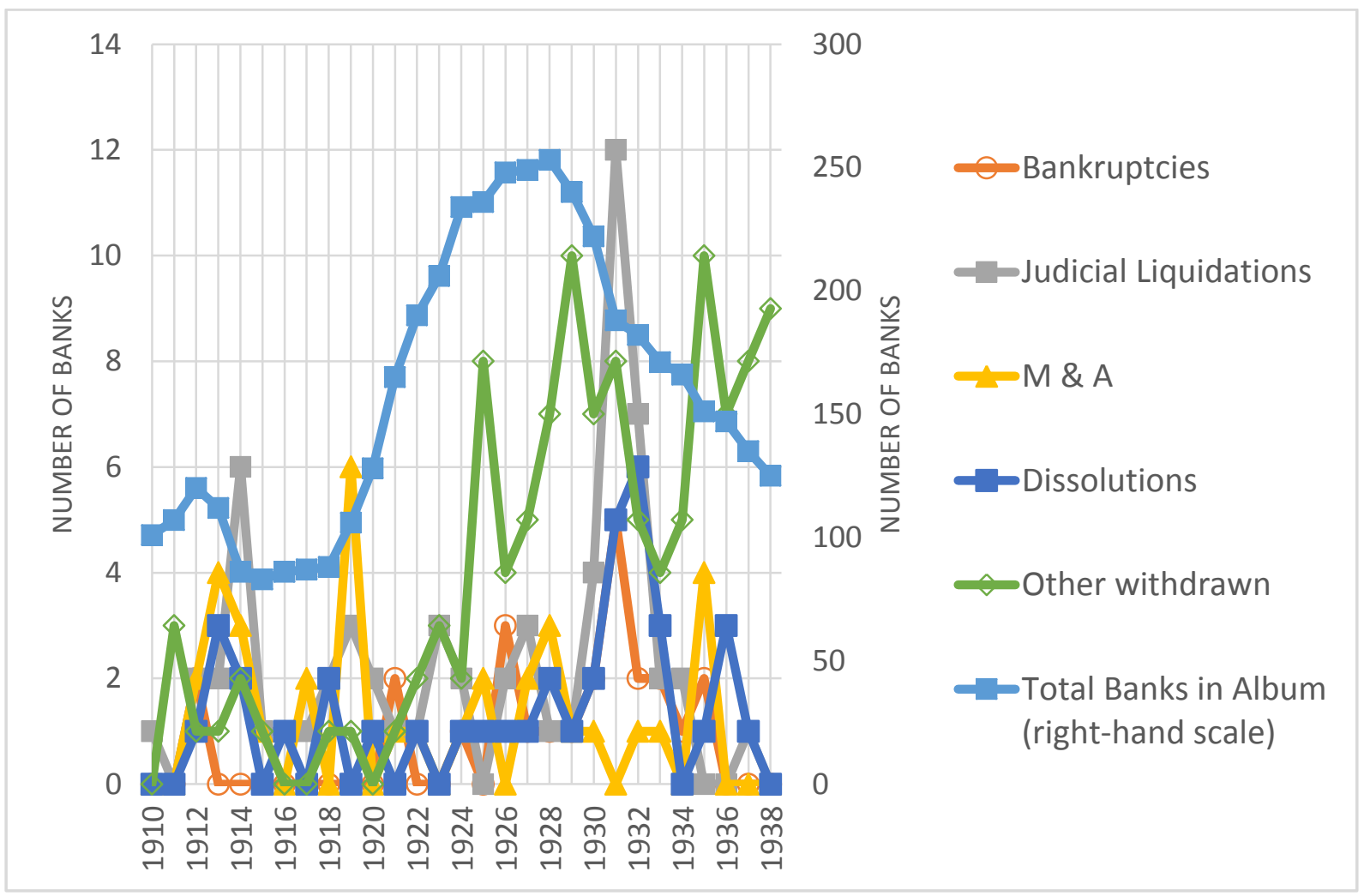

Figure 1: Total number of banks in the Album (right-hand scale) and types of exit (left-hand scale)

\section{Album comprehensiveness}

An initial version of the Album spanned 1901 to 1910 with limited scope. During 1910, Crédit Lyonnais added 50 banks, an increase of $100 \%$ of the number of banks in the Album. From that date, each new entry corresponds to creation of a limited-liability bank. ${ }^{13}$ Between 1901 and 1938, 454 banks appeared at least once in the Album. The turnover of small banks is high, so the maximum number of banks for a year is 250 in 1928 (Figure 1).

When the first banking laws were implemented in 1941, Banque de France gathered balance sheet data for regulated banks starting in 1938. That year was thus used as a benchmark after the war by Banque de France or INSEE (1952) for some monetary statistics

\footnotetext{
${ }^{13}$ We ensured that all entrances corresponded to creation of a limited-liability company. Some institutions existed before in another form but were small at the time they were registered in the Album.
} 
since it was the only pre-war year with statistics available. According to Banque de France, ${ }^{14}$ total deposits and current accounts in 1938 for the entire banking system was 73 billion francs, and total deposits was 70 billion in the Album for the same year. Although the definition for deposits and current accounts might have differed slightly between the Album and the Commission of Bank Control in 1941, these figures are close. After banking regulation was introduced in France and comprehensive banking statistics were constructed, INSEE (1952) noticed that the four large commercial banks accounted for nearly half of total deposits, based on figures from 1938 and 1945. Statistics in the Album show similar results for 1938 - $49 \%$ of deposits in the four largest banks and $51 \%$ in the remainder of the banking system. Another suggestion that the Album was comprehensive is the distribution of deposits across banks (Figure 2), which shows that most banks represented in the Album were very small, further suggesting that Crédit Lyonnais was able to cover all major French banks. In 1929 and of 240 banks, only 21 banks had deposits over 1 billion francs, 25 had over 500 million, and 72 over 100 million (Figure 2). Adding smaller banks to the Album would have influenced total deposits marginally, consistent with the fact that there was no visible break in the series of deposits when the number of banks in the Album increased from 50 to 101 in 1910.

\footnotetext{
${ }^{14}$ BFA (Banque de France archives), 1415200611/43. We found figures on total deposits only for 1938, but not for total assets or the number of banks.
} 


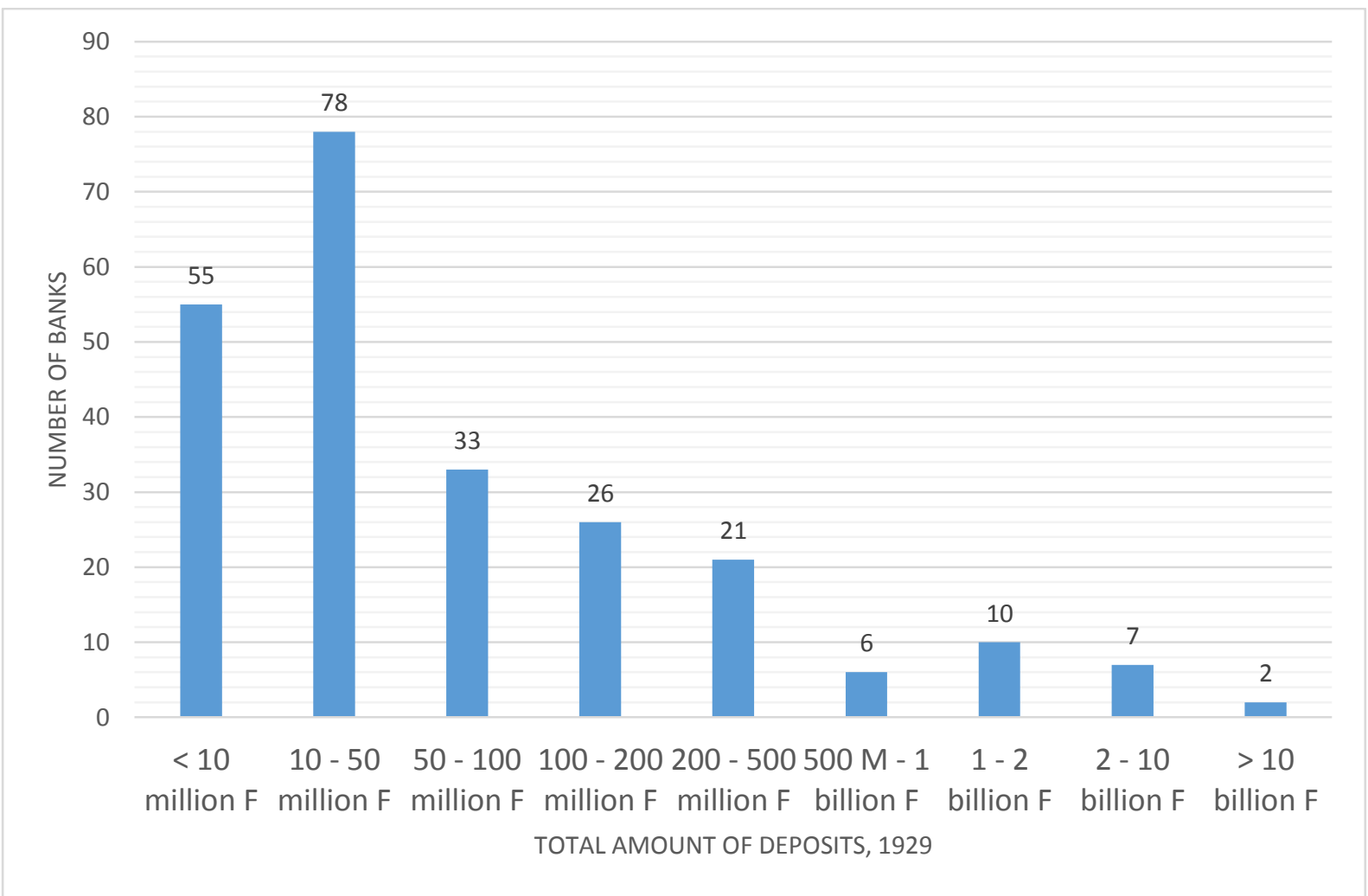

Figure 2: Distribution of bank deposits in 1929 (i.e., number of banks with a given value of deposits)

Figure 3 shows the weight of the banking system in financing of the French economy from 1901 to 1938 . The Figure compares the banking system with the financial market and the primary public or semi-public providers of credit to the economy. Before the First World War, the banking system experienced an important increase; its weight relative to the GDP doubled between 1901 and 1913, from $15 \%$ to $31 \%$ of GDP. The rise was due to strong development of large commercial banks at the beginning of the $20^{\text {th }}$ century (Kaufmann, 1914). The importance of the banking system remained high after the war since the sum of total assets fluctuated between one-fourth and one-third of the French GDP during the interwar period, even though it was dwarfed by the increase in the Banque de France's relative weight due to government debt between 1914 and 1928, and then gold reserves. ${ }^{15}$

\footnotetext{
${ }^{15}$ The sum of total assets of the Bank of France was high, especially in comparison to the Bank of England, whose assets were $11 \%$ of GDP at the time (Duchaussoy and Monnet 2015). During peace time, most assets of the $\mathrm{BdF}$ were invested in gold reserves. During the war and until the monetary reform of 1928 that organized the
} 


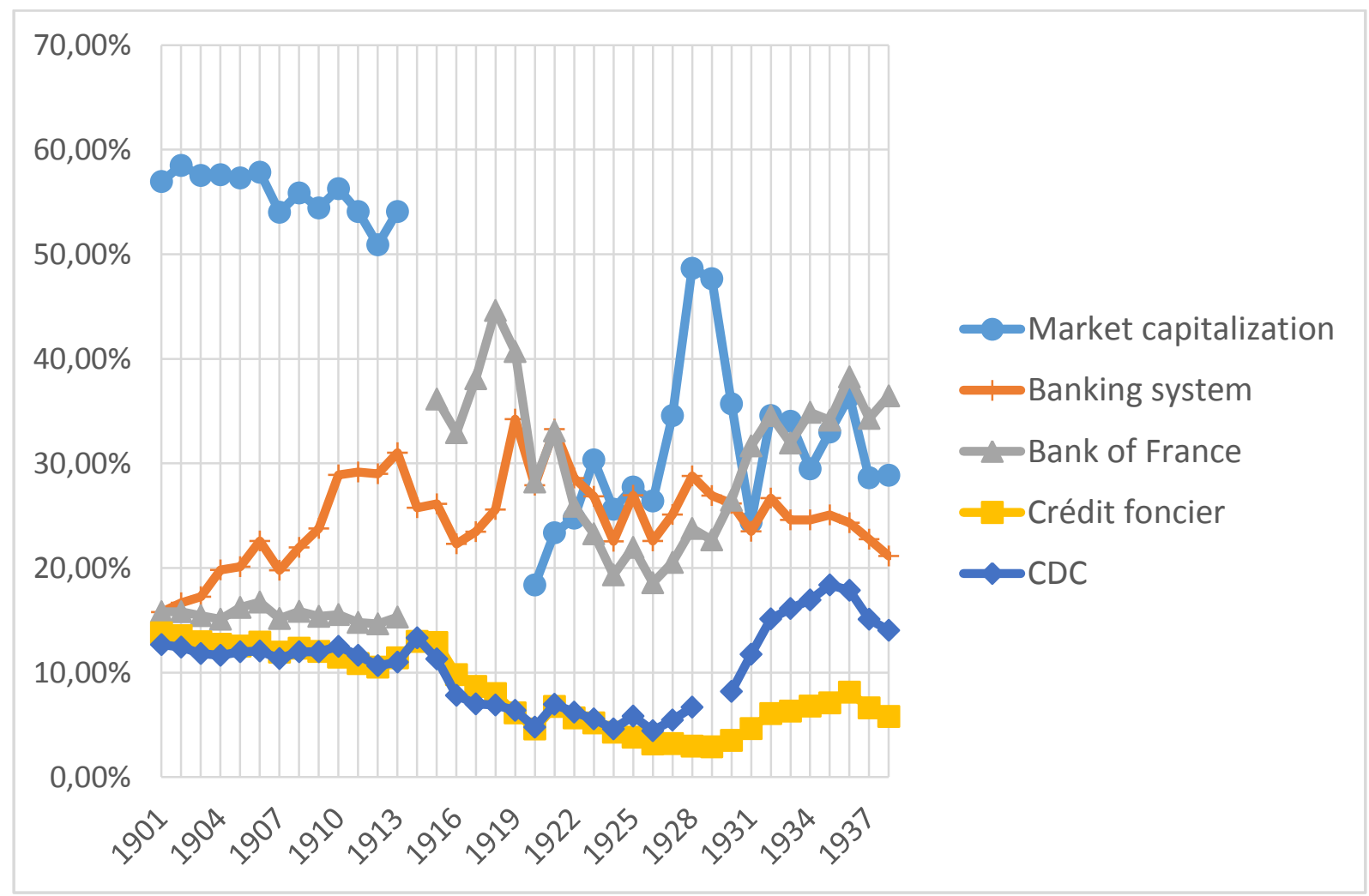

Figure 3: The financing of the French economy, 1901-1938 (assets in \% of GDP)

Notes: All figures are in \% of GDP. Market capitalization of domestic listed companies includes all French official exchanges and the Paris unofficial exchange; the Banking System is the sum of total assets of all banks included in our database, the Album; for Bank of France, Crédit Foncier, and Caisse des Dépôts et Consignations, figures are total assets. Sources: Market Capitalisation: Bozio (2002); Banking system: our DB ; Bank of France: AnnHis (Baubeau, 2018), Crédit Foncier, CDC: Annuaire Statistique 1966; GDP: Piketty (2001).

Balance sheets' items

In the Album, Crédit Lyonnais classified items published in the banks' balance sheets in a simplified and unified balance sheet template, common to all banks. Table 1 shows the standardized balance sheet model produced by Crédit Lyonnais, which has twelve items on the asset side and eight on the liabilities and equity side. This standardized balance sheet was similar to the usual balance sheet of Crédit Lyonnais (Laufenburger 1940). 
Most banks had balance sheet items that were not easily attributable to one of these categories. Thus, approximately 1,500 items appear in the Album, and the majority of bank balance sheets in the Album do not correspond to the layout even after retreatment by Crédit Lyonnais' statisticians. The complete template was used for only the largest banks. For most banks, Crédit Lyonnais either added columns to this general template or merged two columns. For example, short- and long-term deposits, and current accounts, are nearly always merged into one category on the liability side, as are advances on securities, repos, and current accounts (i.e., overdraft credit) on the asset side.

\begin{tabular}{|l|l|}
\hline ASSETS & LIABILITIES and EQUITY \\
\hline Cash at hand and Bank of France & Paid-in share capital \\
\hline Trade receivables (discounts) & Reserves, Provisions, and Retained Earnings \\
\hline Cash equivalents & Net Profit \\
\hline Repos & Short-term deposits \\
\hline Advances on securities & Medium and Long-term deposits \\
\hline Current accounts & Current accounts \\
\hline Accounts receivables & Acceptances \\
\hline Securities & Sundry Accounts \\
\hline Investments in companies & \\
\hline Property, Plant, and Equipment & \\
\hline Sundry accounts & \\
\hline Share Capital not paid-in & \\
\hline
\end{tabular}

Table 1: The Album's standardized balance sheet

Notes: Our translation, based on the translation of banking terms from French by National Monetary Commission, doc. n. 405, 1910, pp 248 and 267. Source: the Album, Archives CASA

To exploit data in the Album and for macroeconomic analysis, we created additional categories. We define broader categories such that we have a complete and homogeneous balance sheet for all banks (Table 2). We classified additional and unusual items into these broad categories based on information from Delaporte (1924) and François-Marsal (1929), 
both encyclopedias on banking and financial activities, and accounting vocabulary for practitioners. These broad categories allow aggregate credit and deposit statistics.

\begin{tabular}{|l|l|}
\hline ASSETS & LIABILITIES and EQUITY \\
\hline Cash & Share capital \\
\hline Commercial portfolio (discounts) & Reserves, Provisions, and Retained Earnings \\
\hline $\begin{array}{l}\text { Advances on securities, repos and current } \\
\text { accounts (overdraft credit) }\end{array}$ & Net Profit \\
\hline Securities and investments in companies & Deposits and current accounts \\
\hline Property, Plant, and Equipment & Acceptances \\
\hline Sundry accounts & Sundry Accounts \\
\hline Called up Share Capital not paid & \\
\hline
\end{tabular}

Table 2 : Simplified balance sheet

\section{A new picture of the interwar French banking crises}

\section{Aggregated statistics}

We compute aggregate series of deposits and credit based on data in the Album and the simplified balance sheet of Table 2. ${ }^{16}$ The widely used series from Saint-Marc (1983), based on INSEE (1952), was constructed by taking the double of the sum of deposits in the four main commercial banks. The League of Nations published a series of total deposits, both short- and long-term, in the balance sheets of the six main banks (i.e., 4 commercial and 2 merchant banks). Figure 4 shows the sum of total deposits and current accounts from the Album, in comparison with the series of banking deposits used in extant research. INSEE (1952) added sundry accounts payable to its definition of deposits, but we argue against this because such accounts usually include guarantees, which today would be accounted as offbalance sheet items.

\footnotetext{
${ }^{16}$ Since some banks were still in the Album during liquidation, and had suspended payments, we exclude these frozen deposits from total deposits (see a subsequent detailed analysis of frozen deposits).
} 


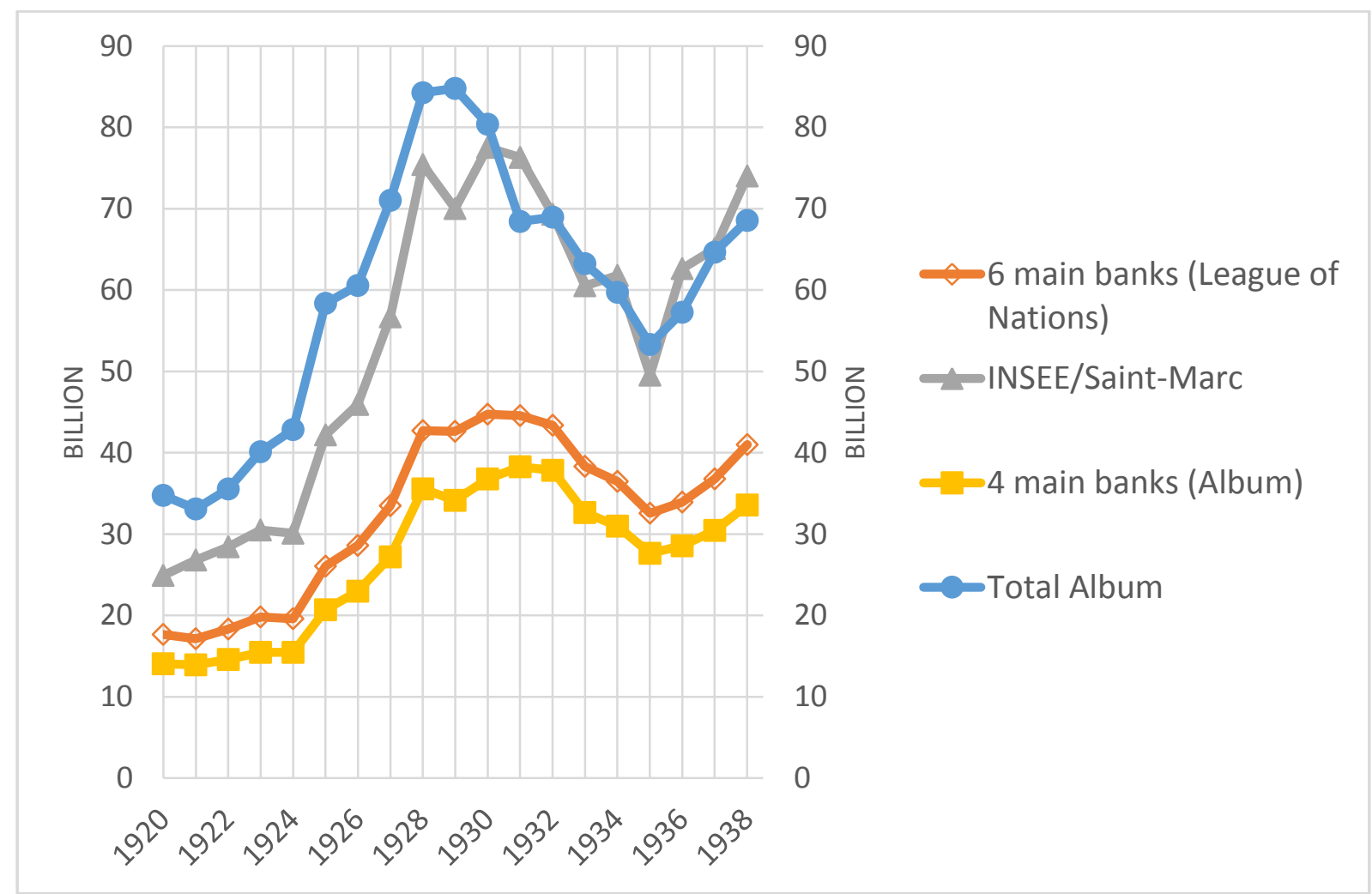

Figure 4: Series of deposits, 1920-1938 (billion francs)

Sources: see the text.

The salient feature of Figure 4 is that all previous series show stability, and even an increase, of deposits between 1929 and 1931. Our series contrarily shows a peak in 1929, followed by a 5.2\% decrease during 1930 and a further $15 \%$ decrease from 1930 to 1931 . Based on 1938 statistics, INSEE (1952) was correct to assume that the 4 largest commercial banks collected half of deposits, but our series shows that it was a false assumption during the 1920s. Figure 5 shows total deposits collected by the banking system and total credit granted by banks to the economy. The series of total credit is the sum of discounts, advances against several types of collateral (including repos), and overdrafts credit (i.e., current accounts). The peak in 1929 was followed by a $6.5 \%$ contraction of credit in 1930 and a further $24 \%$ decrease from 1930 to 1931 . In the credit statistics, we do not include the securities (i.e., shares and bonds) banks held directly, which represent a very small share of bank assets at that time (cf. Figure 20 in the Appendix). 
The interbank money market was small in France during the interwar (Baubeau 2004, Lacoue-Labarthe 2005). The main segment of the money market at the time was the marché des reports, or repo market, a market in which banks were only lenders and borrowers were primarily stock exchange brokers in need of short-term credit. Thus, this was not an interbank market since banks did not refinance themselves through repos (Ungaro 2018). Banque de France did not conduct open market operations on a large scale. In 1929, there were attempts to develop a market for bank acceptances; the central bank started to accept bank acceptances as collateral and a Banque française d'acceptations (French bank for acceptances) was created. We cannot consider interbank credit exhaustively from data in the Album, but can provide some estimations, stressing that Figure 5 would not be modified significantly by considering interbank credit. Interbank financing was not a major component of the aggregate picture. We have information on correspondent accounts on the liability side for only a few banks, which account for $15 \%$ of total deposits in the sample. Therefore, they are not distinguished from other deposits and current accounts in our series (Tables 1 and 2). In these banks, deposits of correspondents decreased slightly more than other deposits from 19301931 , but they were a small part of the total (7\% of deposits on average) and thus contributed little to the overall decrease (cf. figure 30 in the Appendix). We have acceptances on the liability side (85\%-90\% of banks), which are not included in series of deposits (cf. Tables 1 and 2). For a robustness check, we assume that these bills were used for interbank financing. Figure 22 and 23 in the Appendix show that acceptances decreased sharply during the crisis but were very small in comparison to deposits (4\%, on average, of total deposits).

We report statistics nominally, a choice justified by the imprecision of price statistics during this period, and since the purpose is to compare disparate components of the banking system to assess where and when banking panics occurred. Considering the deflated series (Appendix, figure 28), calculated using a consumer price index from Statistique Générale de 
la France, does not change the conclusion about crises during 1930-1931. According to the index, consumer price inflation was high during 1929 (6\%) and moderate during $1930(1 \%)$, and deflation started in 1931 (-4\%), worsening until 1936 when France left the gold standard (-6\%, on average). The decrease in bank deposits between 1929 and 1931 was $21 \%$ nominally and $18 \%$ in real terms. Understandably, real figures are different from nominal figures during the following years of deflation (1932-1935). In real terms, deposits and credit in the banking system in 1936 were equal to their 1931 level; the decrease in banking activity was thus concentrated during 1930-1931.

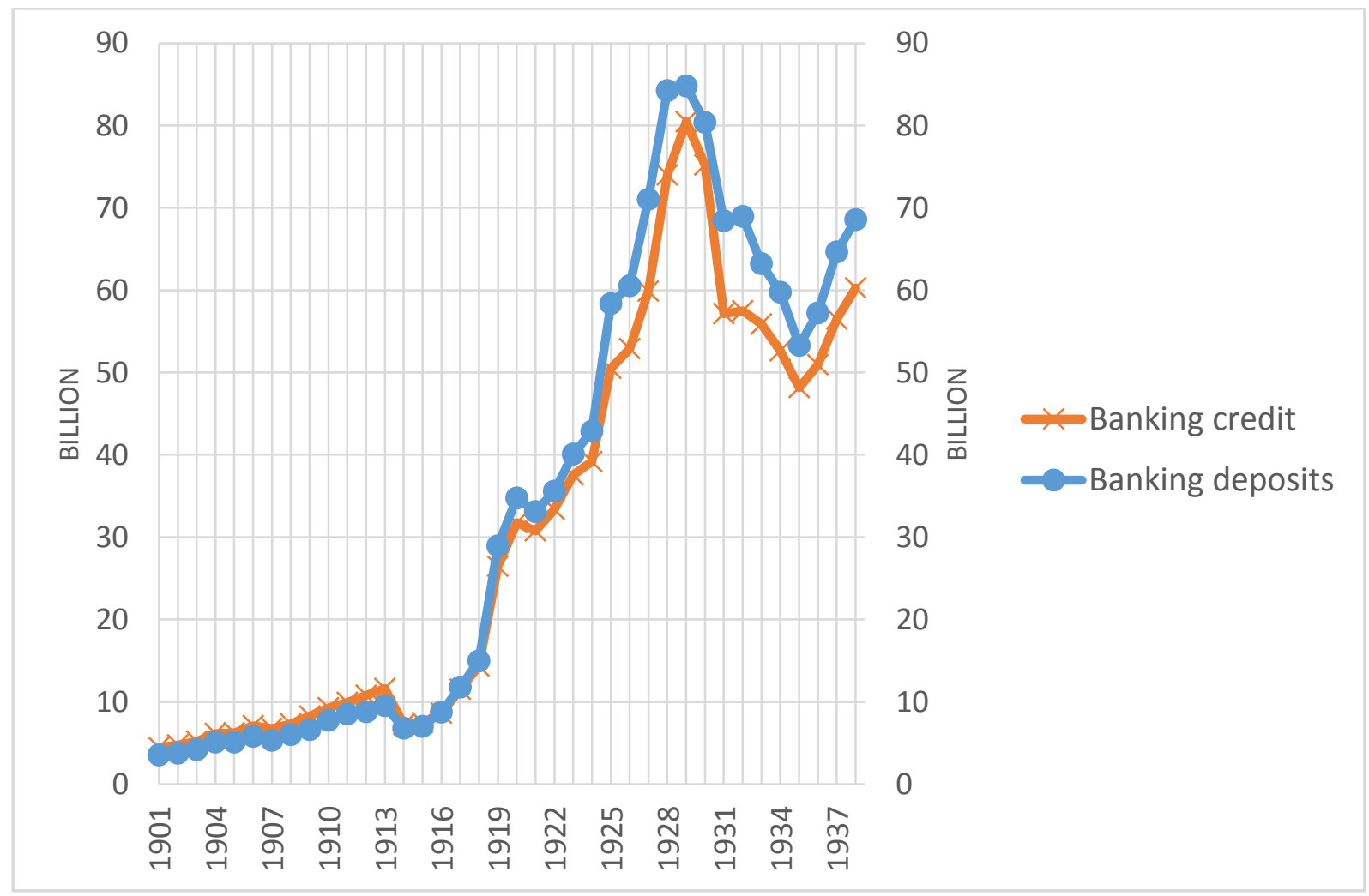

Figure 5: Deposits and Credit, 1901-1938 (billion francs)

\section{Asymmetric crises}

Figure 4 suggests that the depth, or even the existence, of banking panics was overlooked because quantitative sources were limited to a few large banks. Figures 6 and 7 make this argument more obvious by showing the evolution of total deposits and total credit, 
comparing the four main deposit banks to the remainder of the banking system. The rest of the banking system experienced the same growth as the large banks until 1929 (deposits were multiplied by 2.5 from 1920 to 1929), but contrary to the four large banks, it experienced a sharp decrease in both deposit and credit during 1930-1931. By 1931, deposits and credit in the remainder of the banking system had decreased by $40 \%$ with respect to their 1929 levels (Figures 5 and 6). Far from constant, the share of the four large commercial banks in total deposits increased sharply during these two years, from $40 \%$ during 1929 to $56 \%$ during 1931.

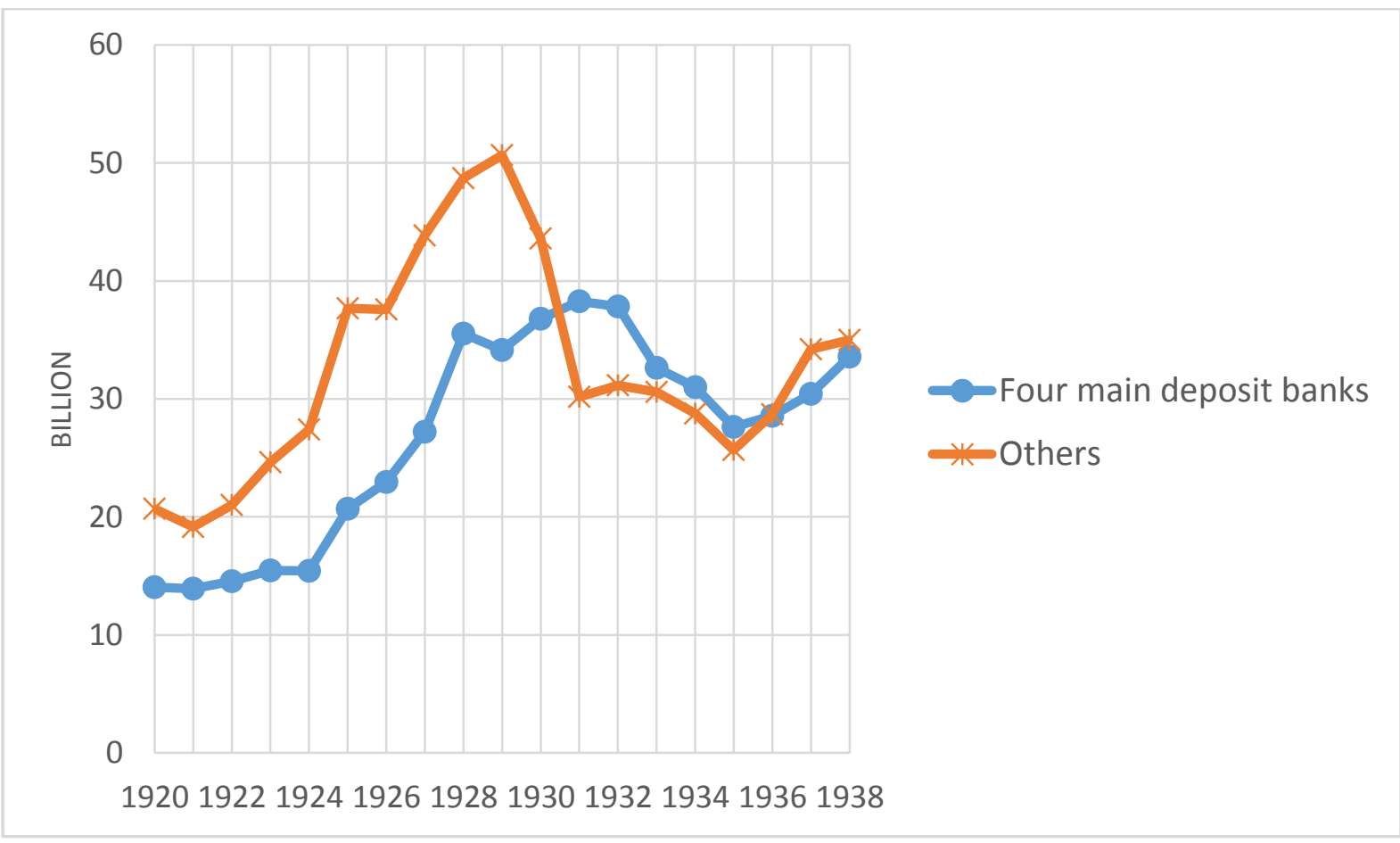

Figure 6 - Total deposits, four main deposit banks vs. rest of the banking system, 19201938. (billion francs) 


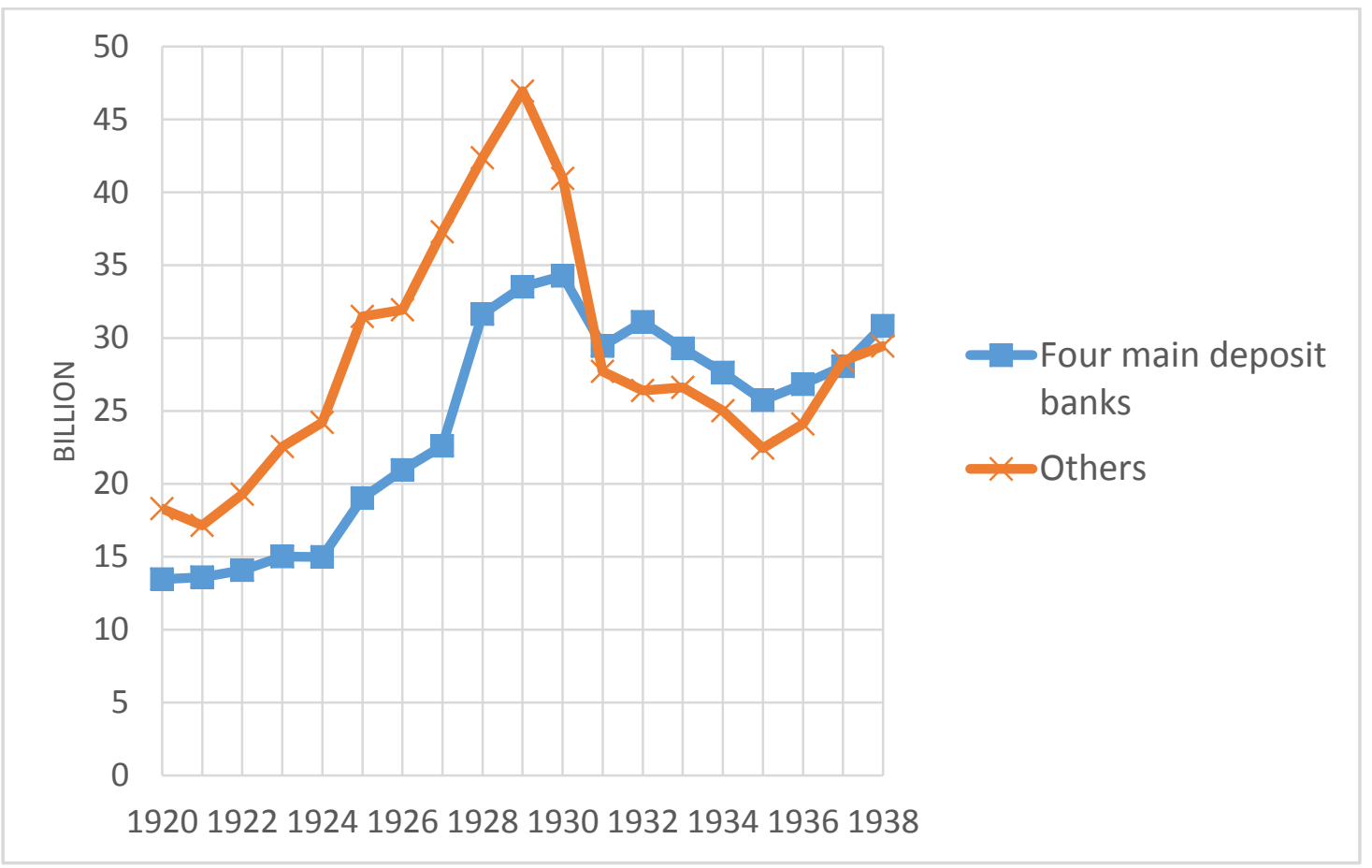

Figure 7 - Total credit, four main deposit banks vs. rest of the banking system, 19201938 (billion francs).

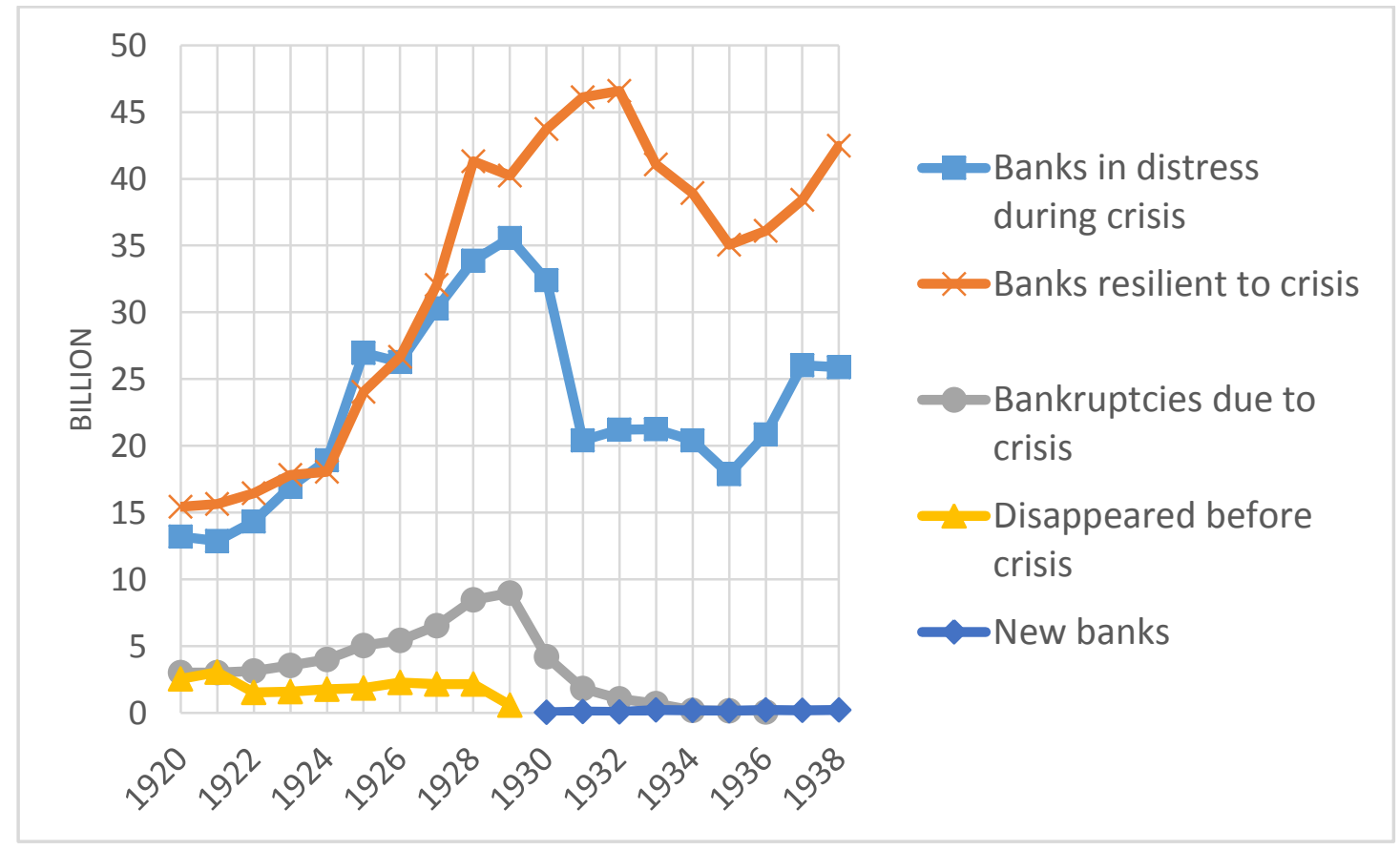

Figure 8 : Total deposits of bankrupt and distressed banks (billion francs)

Notes: Total deposits are both short-term and long term, by all type of clients. Resilient to the crisis are all banks whose deposits increase or remain stable between 1929 and 1931. In distress are all banks whose deposits decrease over the same period (with the exception of those disappearing between 1929 and 1935). 
Banks that lost deposits during the 1930-1931 panics were not only those that went bankrupt (Figure 8). Between 1929 and 1931, 7 billion francs left banks that eventually failed, and 15 billion francs left banks that were in distress but managed to continue their activities. After the panic, banks that had been in distress did not underperform (Figure 8), and banks that either failed or were in distress accounted for 53\% of deposits in 1929 (42\% for distressed, $11 \%$ for failures). From data in the Album, we are able to construct aggregate money and credit statistics that explain what Lacoue-Labarthe (2005) suggested after considering Bonin (2000) and Lescure (2004). Excepting large, oligopolistic banks, the French banking system faced two major panics in 1930 and 1931. Banks that experienced distress or failed exceeded half of total deposits during 1929. This new narrative of the crisis raises two questions. First, was the panic greater in 1930 or 1931? It is important to assess whether the French crises occurred before the international financial contagion that started in May 1931 with the failure of the Austrian Credit Anstalt, and that began again after sterling devaluation in September 1931. Since bank balance sheet data are yearly, we require other sources to document whether the banking panic and the drop in deposits occurred during early 1931, following the first wave of panics that started in October 1930, or during the second half of 1931 at the same time as international contagion. Second, where did deposits go during the panics, and how did the drop in deposits translate to a drop in credit?

\section{New chronology of "an extremely intense crisis of mistrust"}

That a banking crisis occurred as early as 1930 in France is clearly present in qualitative and quantitative information in the archives of the Banque de France, and especially in transcripts of the Conseil Général (i.e., board of governors). In early November 1930, the Conseil Général discussed what was described as a "run on banks,"

\footnotetext{
${ }^{17}$ BFA, CGM, board of directors, November $27^{\text {th }} .1930$.
} 
of several medium-sized banks ${ }^{18}$ (i.e., Adam Bank, Oustric Bank, and Société financière de Paris). These defaults caused financial risk for the Banque since many of these banks were its customers. The risk was sufficiently severe to postpone publication of the Banque de France's annual report on its portfolio (i.e., commercial loans) ${ }^{19}$ and allocate the Banque's budget surplus to the "provision for unpaid bills." ${ }^{20}$ Hautcoeur (1990) recounts lively debates that took place at the board of governors during this period. A staff report on these "unpaid bills" (effets en souffrance) offers a precise image of how the crisis was perceived at the end of December 1930:

The banking crisis, which started abruptly at the end of October, led to numerous insolvencies among the banking houses that were in contact with our establishment ${ }^{21}$.

A new line, "unpaid bills, 1930 on," appeared on the confidential daily balance sheet of the Banque as early as January 1930, but it was not motivated by anticipation of a crisis. ${ }^{22}$ It was added to a previously existing line titled "unpaid bills, 1889 on." This category had been created on the balance sheet of the Banque following the Comptoir d'Escompte crisis during 1889 (Hautcoeur, Riva, and White, 2014). In early 1930, the amount of unpaid bills remained low, and most of these bills were repaid quickly, within a month. We collected the amount of unpaid bills on the daily balance sheet of the Banque de France starting in 1930.

These daily balance sheets were unknown to the public (contrary to weekly balance sheet that was published every Thursday, but did not include a separate item for "unpaid bills") and have not been used until now by historians. Figure 9 shows the end-of-the-month value of these unpaid bills. The category "Unpaid bills, 1889 on" included all unpaid bills that had not been repaid before January 1930. Some of these bills had been there for years, caused largely

\footnotetext{
${ }^{18}$ BFA, CGM, board of directors, November $6^{\text {th }}, 1930$.

${ }^{19}$ BFA, CGM, board of directors, November $27^{\text {th }}, 1930$, p. 417. "As a result of the market crisis, the situation is changing day by day."

${ }^{20}$ BFA, CGM, board of directors, December $4^{\text {th }}, 1930$, p. 444.

${ }^{21}$ BFA, CGM, board of directors, December $26^{\text {th }}, 1930$, p. 505.

${ }^{22}$ BFA, CGM, board of directors, December $26^{\text {th }}, 1929$, p. 437-438. The reason was only to introduce a new item because the previous one, "unpaid bills, 1889 on," was more than 40 years old.
} 
by liquidation of the Bank of China in $1922 .{ }^{23}$ The category "Unpaid bills, 1930 on" was filled for only very brief periods before October 1930, such that end-of-the-month values remained zero. It was only during October that these amounts surged.

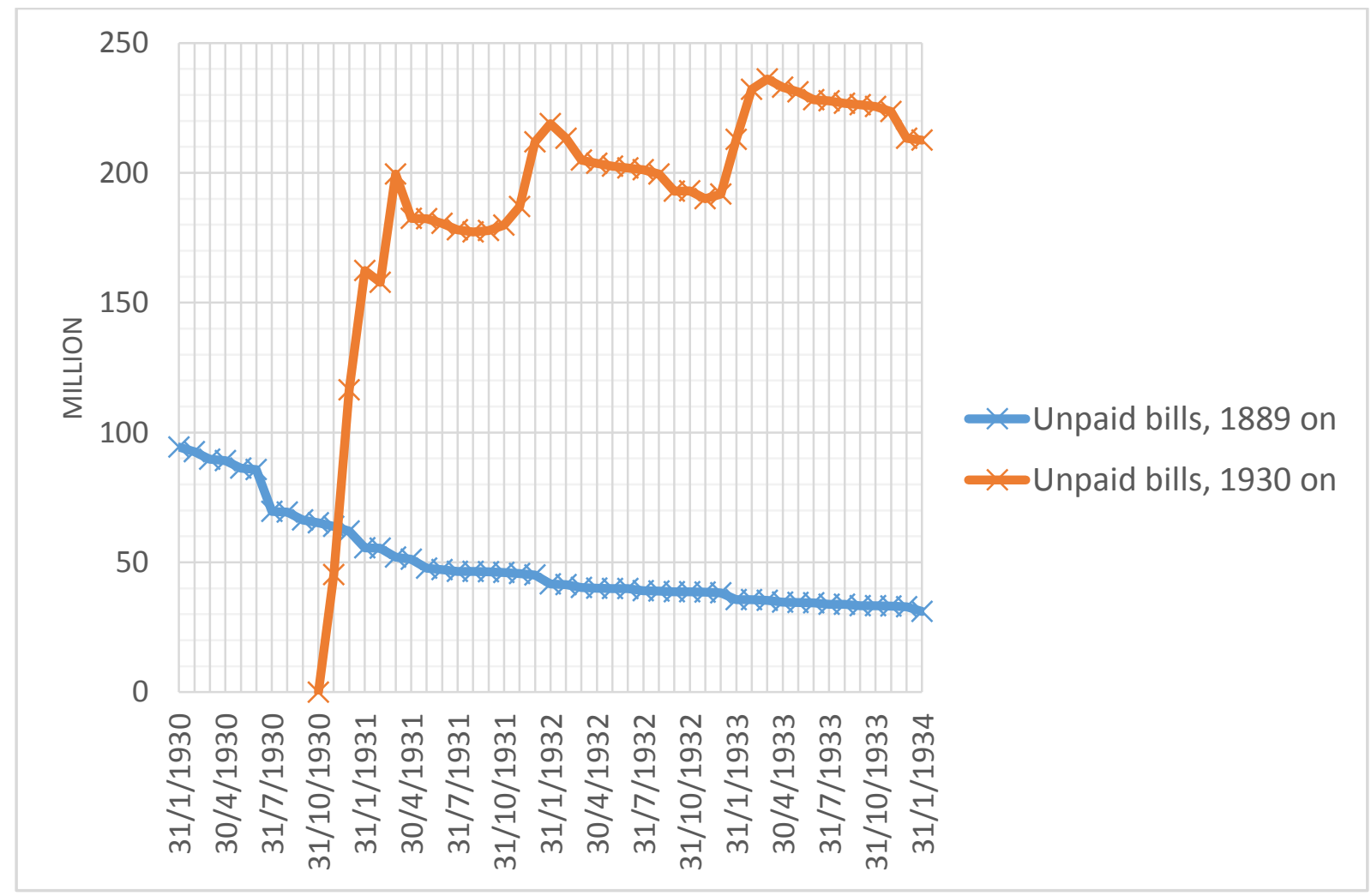

Figure 9 - Unpaid bills at Bank of France. 1930-1933. (million francs) Source: our elaboration from Bank of France archives, Daily accounting ledgers.

During November, December 1930 and January 1931 the amount of unpaid bills registered on the Banque's accounts increased each month by about 50 million. After a pause in February, it reached 200 million in March 1931. The next peak occurred in December 1931 and January 1932, but the increase was much more modest than during the first panic. This series in Figure 9 supports the argument that the French crisis started much earlier than 1931 international contagion. It also suggests that the drop in deposits in annual data for 1931 might be due to a panic in early 1931 rather than the one in late 1931 . Looking at dates of

\footnotetext{
${ }^{23}$ BFA, CGM, board of directors, December $26^{\text {th }}, 1929$, p. $437-438$.
} 
bankruptcies for banks that appear in the Album, scaled by their size before they went bankrupt, losses were larger in Fall 1930 and early 1931 (Figure 10). ${ }^{24}$

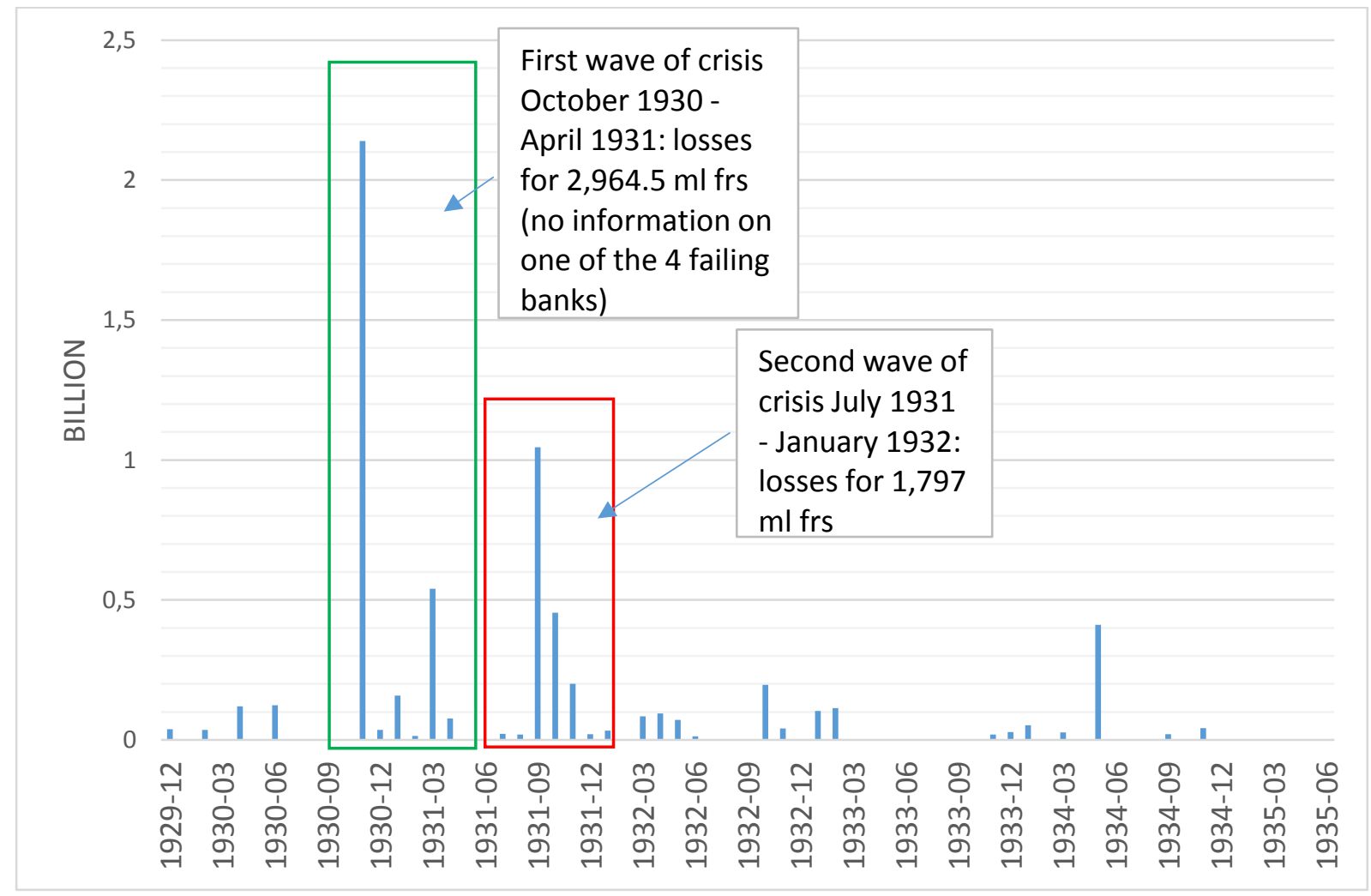

Figure 10: two waves of bankruptcies (bankruptcies or judicial liquidations by month, scaled by the size of the bank)

Besides Banque de France's meetings, the severity of the crisis during late 1930 and early 1931 was not unnoticed by contemporaries. For example, economist J. Loriot wrote in 1931 (Revue d'économie politique, vol. 45, no. 3, p. 584) that "an extremely intense crisis of mistrust" had erupted in November 1930 and continued until spring 1931, though he also

\footnotetext{
${ }^{24}$ The starting month of liquidation or bankruptcy procedures, and balance sheets for the bank at the time, were found in CASA, 129AH110, "Tableau de bord des causes des banques en difficulté" (see below for further descriptions of this source). Banque Nationale du Crédit (BNC) is not considered here as a bankrupt bank since deposits were taken over by a newly created Banque nationale pour le commerce et l'industrie (BNCI).

Suspension of payments lasted only 3 weeks, and thus had no severe monetary effects. For the same reasons, Banque de France did not consider its loans to BNC as delinquent, and did not include them in its "Unpaid bills, 1930 on" account category. See BFA, CGM, board of directors, October $1^{\text {st }}, 1931$.
} 
emphasizes that the largest commercial banks had resisted the panic and even reinforce activities.

\section{Investigating the transmission channels}

One question concerns where deposits went. Traditional answers highlight monetary factors; deposits were either frozen due to bankrupt banks or hoarded as cash by individuals (Friedman \& Schwartz (1963). Were that the case, the decrease in credit could be the consequence of a drop in the money multiplier. Hence, the first step is to calculate the amount of frozen deposits, and the second to estimate hoarded cash. A third step demonstrates that the majority of deposits were neither frozen nor hoarded cash, but they fled to safe deposit institutions (Caisses d'épargne) and the central bank.

\section{Frozen deposits and bankruptcies laws}

Another question is what happened to deposits when a bank went bankrupt. Since banking was not the object of specific regulations, banks and bankers were subjected to the same rules and jurisprudence as industrial and commercial companies were. ${ }^{25}$ During 1889 , judicial liquidation (liquidation judiciaire) was introduced to the French juridical system to preserve the company. Judicial liquidation concerned the conclusion of settlement agreements between creditors and debtors, the latter of whom did not lose control of their businesses in the process. If insolvency was deemed the consequence of adverse circumstances, the company could demand judicial liquidation; the company tried to reach a concordat with the creditors under the supervision of a liquidator (liquidateur). If an agreement was reached, the entrepreneur was entitled to carry on activities, but if not, bankruptcy began (Hautcoeur and Levratto, 2011). In the case of bankruptcy, the appointed trustee established a balance sheet

\footnotetext{
${ }^{25}$ The only rules specific to banking concerned exclusion from banking activity by persons condemned for an offense during June 1930 and then generalized in 1935 (Prévost and Pissavy A., 1936, Ripert, 1948).
} 
by distinguishing secured and unsecured creditors. Secured creditors were reimbursed through their guarantees, ${ }^{26}$ and the trustee recovered the company's credits and liquidated remaining assets. Revenues were distributed to unsecured creditors proportionally. If revenues from liquidation covered reimbursement to unsecured creditors, the remainder was distributed among shareholders. Otherwise, creditors suffered losses. Bank clients with a deposit account, on demand or fixed term, were deemed unsecured creditors by default, and they were unentitled to individual actions regarding getting their money back. The opening of a bankruptcy closed deposit accounts immediately and made fixed-term deposits due and payable immediately. Bank clients with a current account and a positive balance were encompassed in the same category, and the accounts were closed by default at the beginning of the procedure. ${ }^{27}$ Even under bankruptcy, commercial judges could authorize a temporary continuing of a company's activity if it might offer additional revenues to creditors (Percerou, 1935; Ripert, 1946). However, during this phase, deposits could not be withdrawn on demand, and payments to depositors and other creditors were made only according to the proportional rule of the procedure.

Several banks that had entered a bankruptcy procedure remained in the Album for some years to reimburse creditors, including depositors, because liquidation took time. We correct the series of deposits from the Album to account for this issue, due to another document available in Crédit Lyonnais' archives that provides a detailed, quantitative account of the bankruptcy and liquidation procedures of banks. ${ }^{28}$ The document was produced for internal use in 1935. For each bankrupt bank, it provides information on the amount of deposits that was frozen on December 31, 1934. The document also contains the start date of

\footnotetext{
${ }^{26}$ This was typically the position of Banque de France, which explains why it suffered only little losses during the crisis.

${ }^{27}$ As a consequence, the interests on the positive balances of deposits and current accounts from the start of the procedure were not taken into account in the credits of the failing bank's clients. These interests could only be paid with the potential residual after the payments of all the creditors and before the distribution to shareholders (Clerc, 1935).

${ }^{28}$ CASA, 129AH110, "Tableau de bord des causes des banques en difficulté".
} 
a bankruptcy procedure for each bank. For each institution, we consider the amount of deposits at the end of 1934 as frozen from the start date of the bankruptcy procedure to the end of 1934. This information allows us to construct an aggregate series of frozen deposits in the banking system from 1929 to 1934 . We estimate the amount of frozen deposits at 1.58 billion francs in 1930, 2.18 billion in 1931, 2.51 billion in 1933, and 3.07 billion in 1934 . Although not negligible, these amounts do not account for the bulk of the decline in bank deposits, which decreased by 25 billion francs from 1929-1934.

\section{Hoarded cash}

Changes to circulation of banknotes with large denominations provide a way to estimate currency hoarding. ${ }^{29}$ Banque de France used these notes as a proxy for hoarded cash, a phenomenon it identified as soon as December 1930; "It appears that the newly issued notes [which were of the larger denominations] are largely hoarded." ${ }^{, 30}$ Among other contemporary writers, Séguin (1938) also considers large denominations of banknotes to be largely hoarded. Figure 9 shows the amount of fiduciary circulation in France from 1920 to 1938 by banknote denomination, aggregated into small and large categories. Between 1929 and 1932, the circulation of small banknotes was stable. All increases can therefore be attributed to large denominations. The increase in large-denomination banknotes was steeper from the end of 1929 to the end of 1931, during the peak of the banking crisis. According to Banque de France's annual report for 1930, cash hoarding was especially strong during spring 1930 before the crisis because of large capital inflows. ${ }^{31}$

\footnotetext{
${ }^{29}$ Monetary circulation of gold was discontinued permanently in France after 1914, and that of silver remained marginal, so we have no indication of foreign currency hoarding apart from gold coins.

${ }^{30}$ BFA, CGM, board of directors, December $4^{\text {th }}, 1930$, p. 419. "Il semble que les billets nouvellement émis soient en grande partie thésaurisés."

${ }^{31}$ Rapport aux actionnaires de la Banque, 1931.
} 


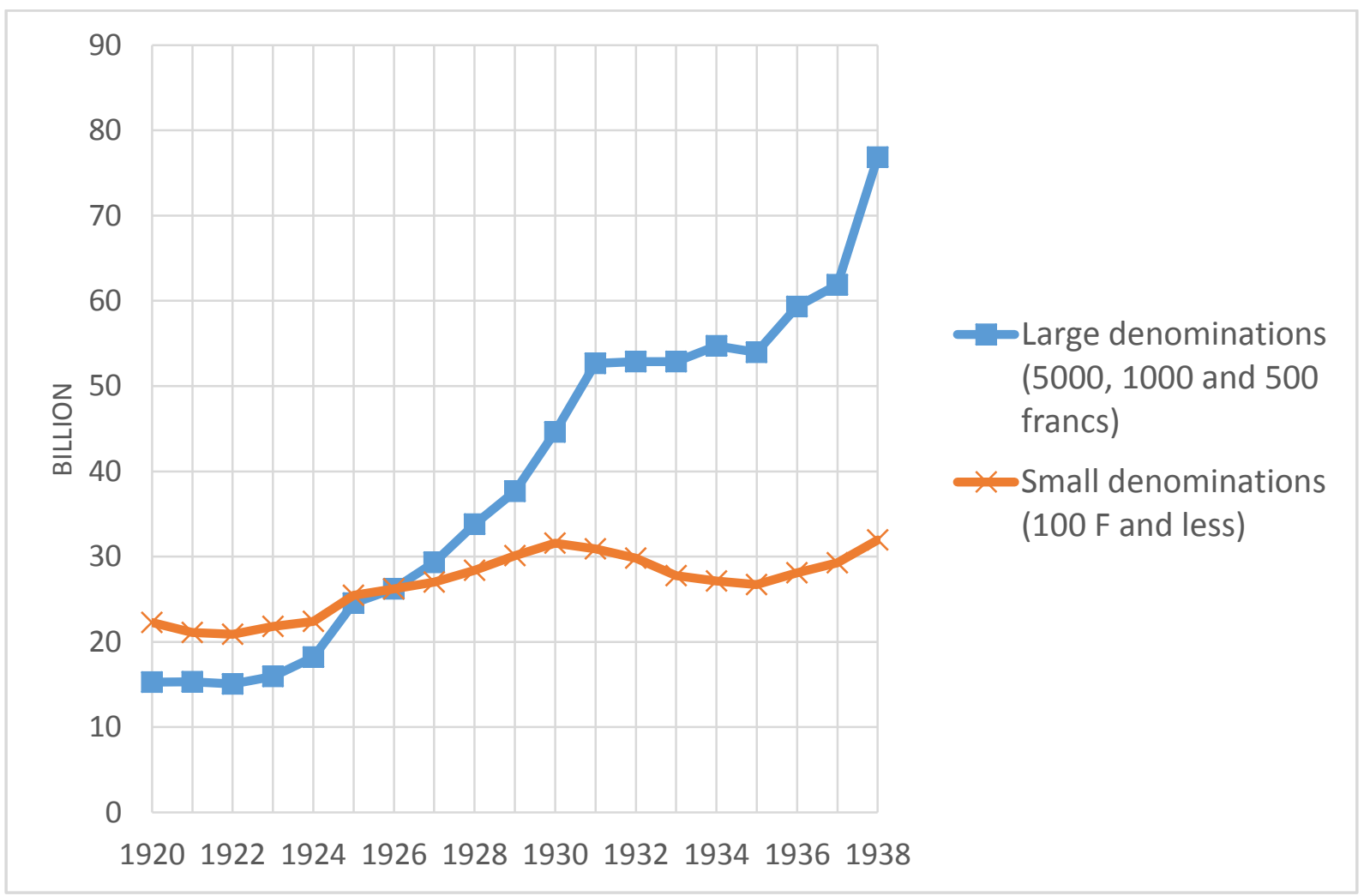

Figure 11. Fiduciary circulation in France, by banknotes denomination (billion francs). Sources : annual reports of the Banque de France

\section{Caisses d'épargne}

Caisses d'épargne were French savings institutions, and were not included in the Album. Calling them banks is misleading since they did not lend but only managed a portfolio of French long-term Treasury bonds. They were created and extended in two forms, both under state regulation, ${ }^{32}$ contrary to banks, regarding incorporation and their range of operations. Starting in 1818, independent savings banks were created at the town level, sometimes branching sub-departmentally (Christen-Lécuyer 2004). In 1882, a new state service was created, the Caisse nationale d'épargne (National saving bank), which branched across France by being incorporated in the post office network. From then on, two types of saving banks (Caisses d'épargne) co-existed - the Caisses ordinaires (private) and the Caisse

\footnotetext{
${ }^{32}$ Which did not prevent a few bankruptcies to occur nor a major liquidity crisis in 1848 . See Christen-Lécuyer (2004).
} 
nationale (state-owned) - both dedicated to safe collection of petty savings in exchange for low interest rates. Both Caisses did not invest deposits in lending to corporations but in Treasury bonds and perpetual annuities (Rente). Starting in 1895, funds of the Caisses d'épargne were, by law, centralized and managed by the Caisse des dépôts et consignations (CDC), a state-led financial institution created in 1816. Due to their status, management, and investment constraints, Caisses were considered safe institutions in which to deposit money. There was no formal deposit insurance, but funds were de facto guaranteed by the French State since assets of the Caisses d'épargne, managed by the CDC, were invested in governments securities. These deposits were very liquid. By law, deposits had to be reimbursed at 8 days of view, but in practice, payment was almost always immediate (Coupry 1935). Interest rates on deposits were regulated by the government (see Levy-Garboua \& Monnet 2017 for series of their interest rates). Deposit accounts had a legal maximum set by Parliament. Information on the amount of deposits collected each year is available on annual reports of the Caisse Nationale d'épargne (CNE) and of Caisses Ordinaires d'épargne (CEO). During March 1931 and due to inflows of deposits, the maximum was increased from 12,000 to 20,000 francs for individuals and 50,000 to 100,000 for corporations. Although the French economy was in crisis, several representatives asked for a law allowing Caisse d'épargne to buy nongovernment securities and lend to businesses, but such proposals did not pass (Coupry 1935). 


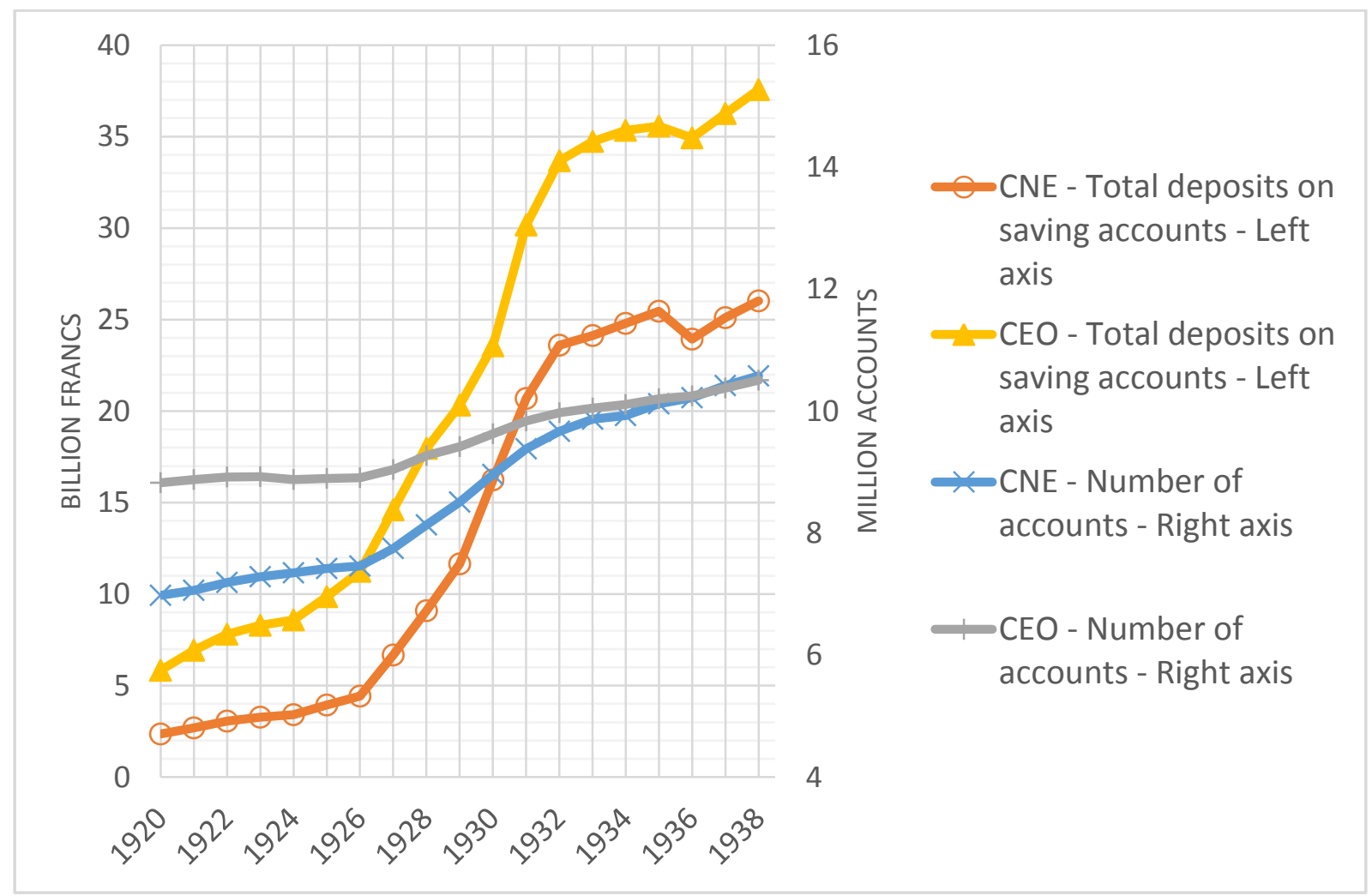

Figure 12. Caisse nationale d'épargne (CNE) and Caisses ordinaires d'épargne (CEO). Total number of accounts and outstanding amounts on savings \& deposits accounts, end of year. Sources : Bulletin de statistique et de législation compare and Statistiques et Etudes Financières, vol. 12, $n^{\circ} 144$.

Deposits in both CNE and CNO multiplied by more than 2 between 1929 and 1931, an increase that was unprecedented, though it began just after stabilization of the franc and a rise of capital inflows after 1926 (Figure 12). ${ }^{33}$ Monthly data available for Caisse Nationale d'épargne only show a sharp increase during late 1930 and again in late 1931, coherent with the chronology of the crisis (see Appendix, Figure 26). Consistent with other data, the first wave of banking panics between October 1930 and March 1931 appear to be the essential phase of the flight-to-safety.

\footnotetext{
${ }^{33}$ Bonin (1999) noticed a tremendous increase in these deposits during the period and attributed it largely to capital inflows.
} 


\section{Deposits with the central bank}

Another institution that attracted deposits in times of trouble was the central bank. The weekly balance sheet of Banque de France is available from Baubeau (2018). The item “individuals' current accounts" (comptes courants des particuliers) experienced a strong increase during 1930 and 1931 (Figure 18). However, the item also included banks' current accounts. We therefore subtract amounts deposited at Banque de France (Figure 17) by the four main banks from these current accounts. This estimation is imprecise, but we assume that only banks unaffected by the crisis (i.e., the 4 large commercial banks) were likely in a position to deposit (large) reserves at the central bank (see below for more). ${ }^{34}$

\section{Summing up financial flows}

In the upper parts of the bars (above zero), Figure 13 shows positive cashflows in institutions that attracted deposits and hoarded cash from 1930-1931. In the lower parts (below zero), we estimate from where these positive cashflows came-deposits leaking out of the banking system and capital inflows from abroad. This reconstruction of the French flow of funds assesses the consistency of our interpretation of the crisis, considering that France was a net receiver of foreign capital at the same time. We begin with equality:

Inflows of foreign capital + Total decrease of deposits in the banking system $=$

Hoarded cash (i.e., increase in banknotes circulation) + New deposits in Caisses d'épargne + New deposits at the Banque de France (excluding banks reserves) + Frozen deposits

Estimations of the categories above are imprecise and incomplete, and we might miss other uses of capital inflows. Measurement of capital flows is especially subject to caveats (Sicsic 1993). However, Figure 13 shows that our computations of positive and negative

\footnotetext{
${ }^{34}$ BFA, 1069201116/48-71. Cash and deposits with the central bank were obtained from monthly balance sheets available in Banque de France archives.
} 
flows nearly match, though the flow of resources (i.e., decreasing bank deposits and increasing capital flows) is slightly smaller than the flow of uses (i.e., increase to deposits in Caisses d'épargne, etc.). Frozen deposits never exceeded $10 \%$ of flows and were much lower than flows of deposits to safe institutions (i.e., Banque de France and nearly all Caisses d'Epargne) and hoarded currency, measured by an increase in large banknotes circulation. Flight-to-safe deposits and money hoarding reached equivalent volumes in 1930, and flightto-safe deposits became predominant in 1931. In both 1930 and 1931, the increase in deposits in Caisses d'épargne exceeded the decrease of deposits in the banking system. Inflows of foreign capital also contributed to an increase in Caisses d'épargne's deposits during the crisis.

40

1930

1931

30

20

10

0

(1)

$-10$

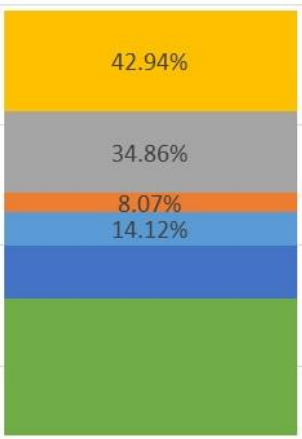

$-20$

$-30$

Increase of deposits in BoF

Increase in banknotes circulation

Frozen deposits

- Decrease in deposits in banking system Capital flows

Figure 13 : Flows of funds, 1930 and 1931 
Previous sections demonstrate that French banking panics were characterized by flightto-safety deposits from banks, which did not offer sufficient guarantees to creditors, to safe institutions (i.e., Banque de France and Caisses d'épargne), which offered de facto guarantees because of strong ties to the state. As a result and as shown in Figure 14, total deposits, including those of Caisse d'épargne and our estimation of nonbank deposits in central banks, increased during the crisis because few deposits were frozen or hoarded as cash in comparison to massive capital inflows.

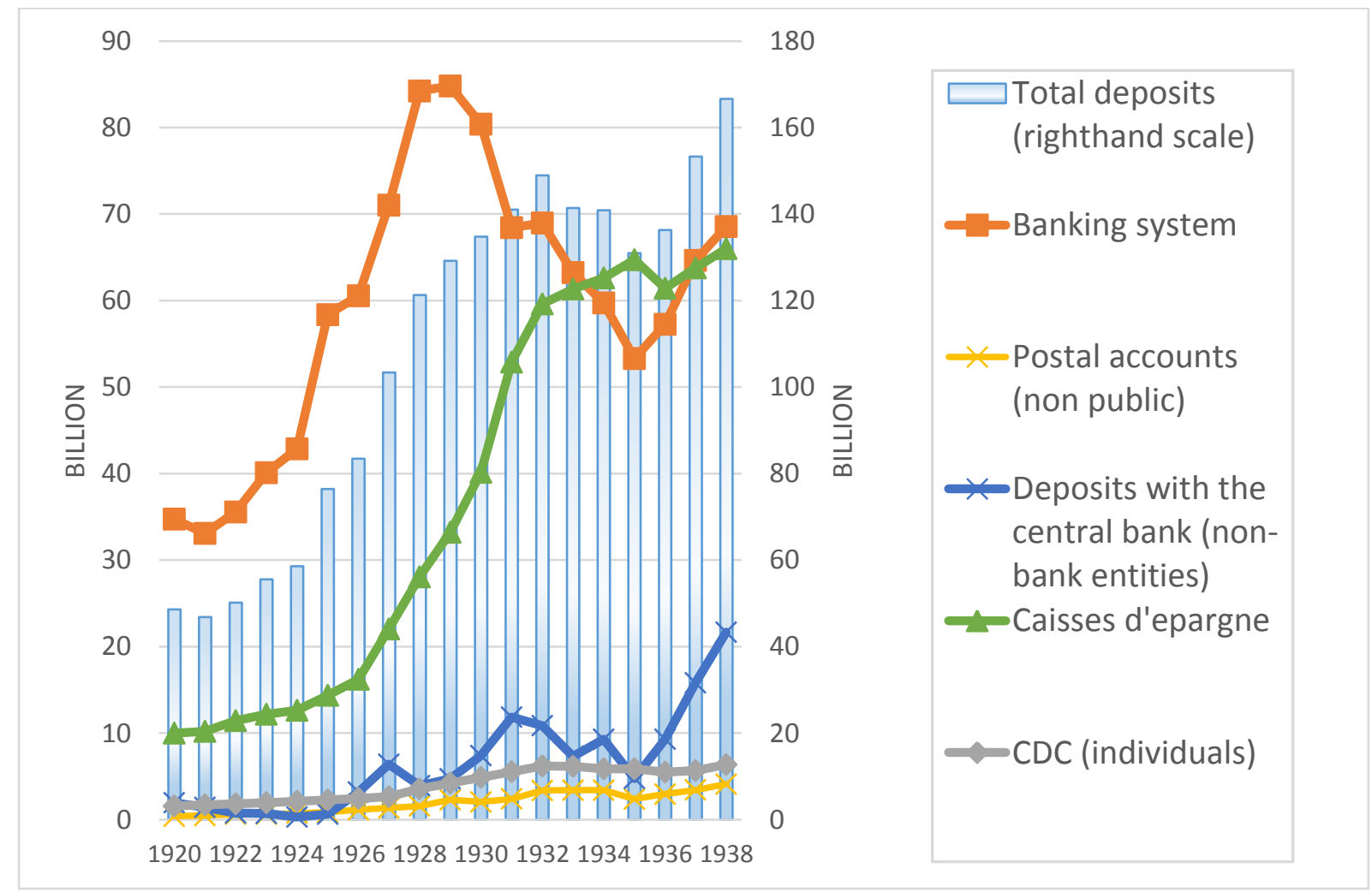

Figure 14 : Total deposits in France, 1920-1938 (banks and savings institutions)

The question then is whether the crisis was benign. Is a nonmonetary effect of a banking panic possible if there was no monetary effect? To answer this question, we investigate what safe institutions (i.e., Caisses d'épargne and Banque de France) did with the extra money. Did they replace the banking system as financial intermediaries and then avoid a credit crunch, or did they freeze credit? 
Information from Caisses d'Epargne annual reports shows that during 1930, and even more in 1931, the only growing balance sheet item on the asset side was "current account at the Caisse des Dépôts" (Figure 15). Since it managed Caisses d'Epargne assets, CDC could also fund the Treasury directly instead of buying annuities and bonds. The cash was used to reduce the nominal amount of public debt issued on the market, in the context of post-1928 stabilization policy (Mouré 1991). Caisses d'épargne did not use the new inflow of deposits to buy government securities as it would normally. Instead, the Treasury used cash directly to decrease marketable government debt (Table 3) and the need to float new Treasury bonds. Official French public debt in nominal terms (outstanding stock of issued bonds) decreased from 224 billion in 1929 to 207 in 1931, and reached a low point in 1933 at 181 billion (INSEE, 1966).

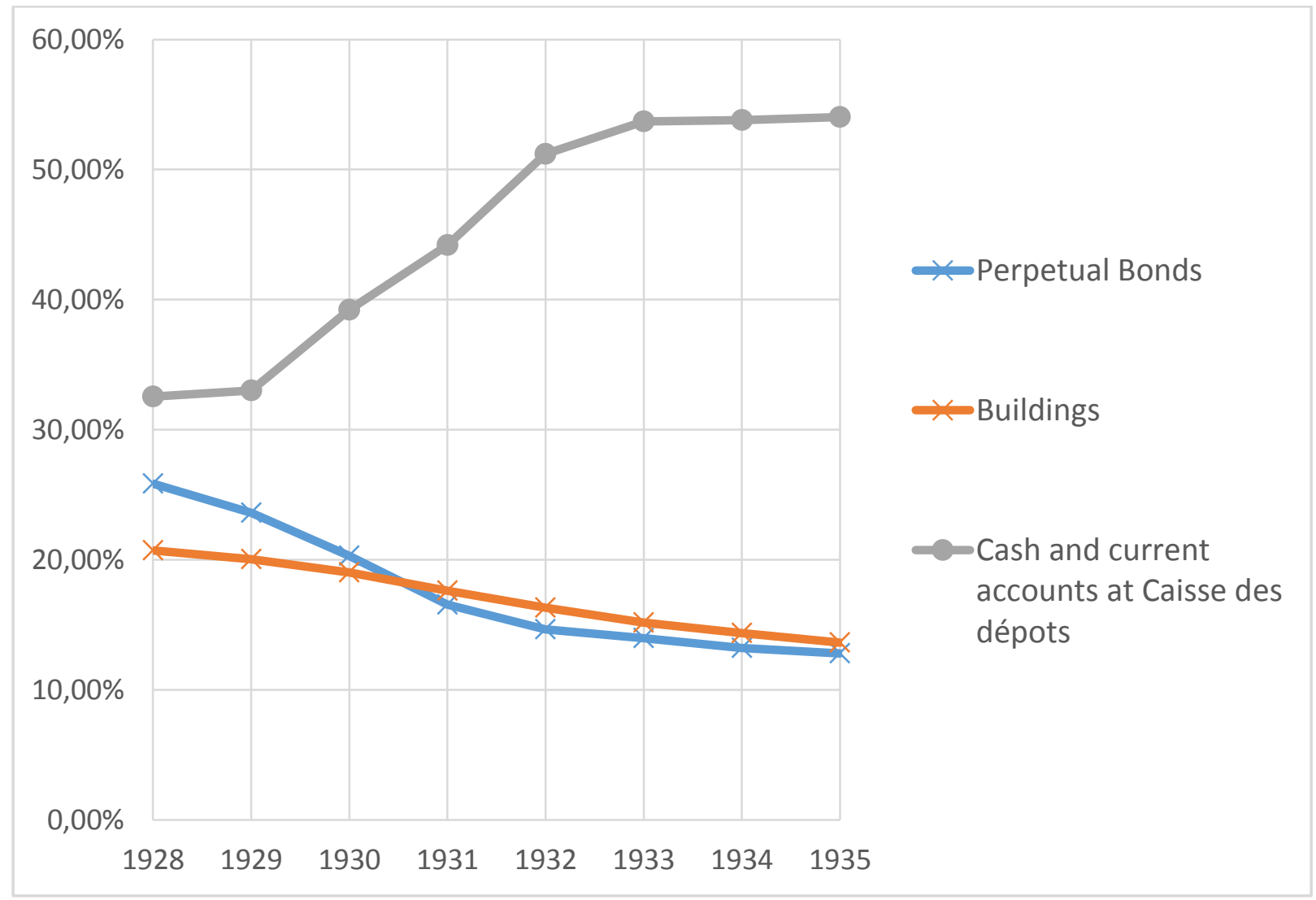


Figure 15 : Evolution of main asset side items, Caisses d'épargne

Sources : Annual reports of Caisses d'épargne

\begin{tabular}{|lllll|}
\hline $\begin{array}{l}\text { Date (January } \\
1 \text { st) }\end{array}$ & $\begin{array}{l}\text { Perpetual } \\
\text { (Rente) }\end{array}$ & Long-term & Short-term & $\begin{array}{l}\text { Total (excepted } \\
\text { correspondants } \\
\text { and public } \\
\text { entities) }\end{array}$ \\
1929 & 103245 & 81696 & 27633 & 212574 \\
1930 & 99906 & 81563 & 34736 & 216205 \\
1931 & 97145 & 91826 & 18124 & 207095 \\
1932 & 96830 & 83193 & 22436 & 202459 \\
1933 & 52996 & 87122 & 21400 & 161518 \\
1934 & 52769 & 139917 & 21045 & 213731 \\
1935 & 52360 & 148569 & 26940 & 227869 \\
1936 & 51388 & 150241 & 27609 & 229238 \\
\hline
\end{tabular}

Table 3 : Marketable Public debt

Source : Statistique Générale de la France. Annuaire rétrospectif INSEE 1966

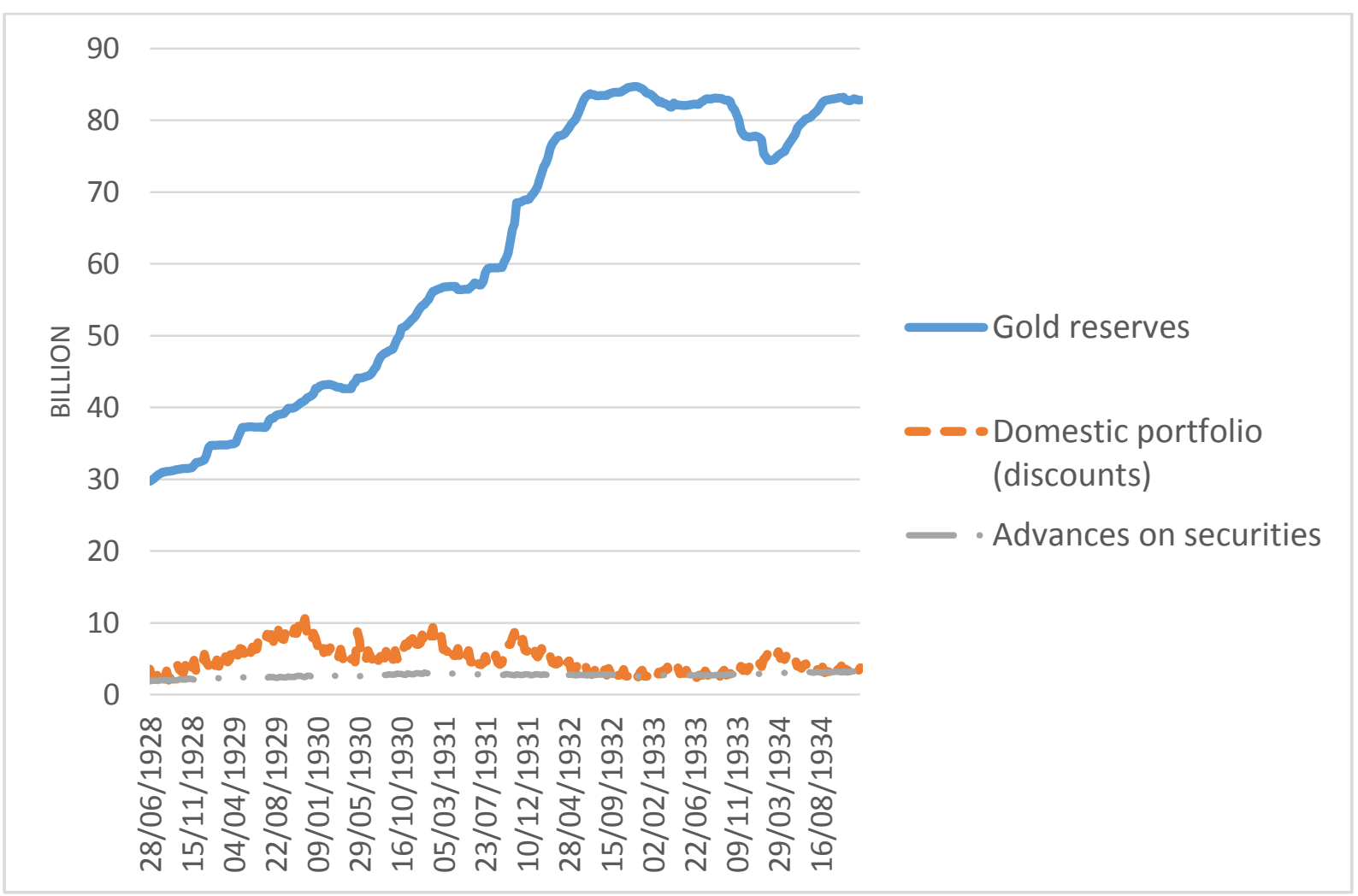

Figure 16 : Gold reserves vs domestic portfolio of the Banque de France (1928-1934) 
At Banque de France, the only items on the asset side of its balance sheet that experienced massive growth were gold reserves (Figure 16), with figures underestimated because the Banque hid some gold acquired in miscellaneous accounts. ${ }^{35}$ It increased its credit to the economy slightly at the conclusion of 1930 and 1931, but in very modest proportion to the increase in gold reserves (Figure 16). The Banque was occasionally accused by contemporaries of replacing the activity of private banks during the crisis and increasing direct lending to private, nonfinancial companies (Hautcoeur 1990, Gonjo 1996). These amounts were, however, negligible in relation to the decline in bank credit to the economy. Some estimates of Banque's lending to nonbank institutions are available only after 1933, and point to $40 \%$ of the total. Figure 19 shows that figures of total credit barely change if an estimate of Banque de France loans to the economy is included.

A related question is whether large commercial banks that did not experience a crisis (i.e., Crédit Lyonnais even experienced a deposit rise) increased lending to businesses to replace the role of failing banks. Large-deposit banks reacted to the crisis by increasing cash and deposits strongly at the central bank (i.e., building liquidity). Figure 17 shows the evolution of balance sheet item "Cash and Account at Bank of France" of the four main deposit banks from 1920 to 1938 . The graph shows a strong decline from 1927 to 1928 , and a sharp increase from 1930 to 1931 . The increase is explained by capital inflows to France following the European currency crises that succeeded each other from June 1931 and that culminated with devaluation of the sterling in September 1931. This is mirrored in current accounts at Banque de France (Figure 18), which include both deposits by banks and by nonbank customers.

\footnotetext{
${ }^{35}$ BFA, CGM, board of directors, February $8^{\text {th }}, 1934$. The governor explains to the board that the (hidden) special gold reserve is being used to average gold movements in published weekly balance sheets. Its amount at the time is 1.74 billion Francs, a huge sum.
} 
Analysis of the assets of Caisses d'épargne, Banque de France, and four main commercial banks shows that these institutions did not replace failed or distressed banks regarding extending new credit. The Treasury used part of the cash deposited in Caisse d'épargne to repay public debt rather than lend to corporations. Repayment of public debt amounts to a cash transfer to bond holders, including large banks, that hoarded it or deposited it in safe institutions. At the end of the chain, the gigantic increase in gold reserves of the Banque de France (40 billion in two years) seems to have absorbed all funds at the expense of loans to the economy.

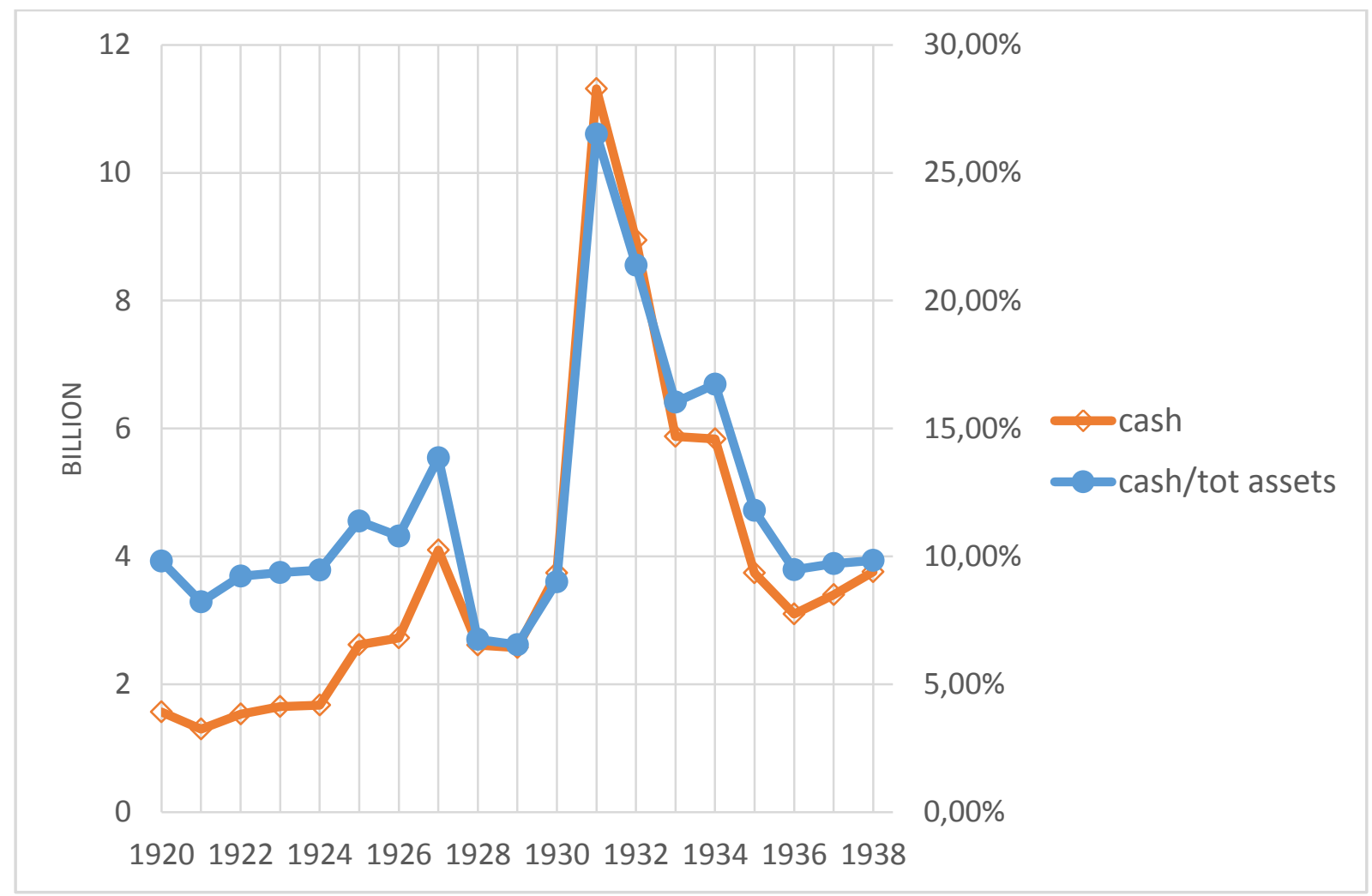

Figure 17 : Cash held at Bank of France by the four main commercial banks, 1920-1938 (total in million and in \% of their assets). 


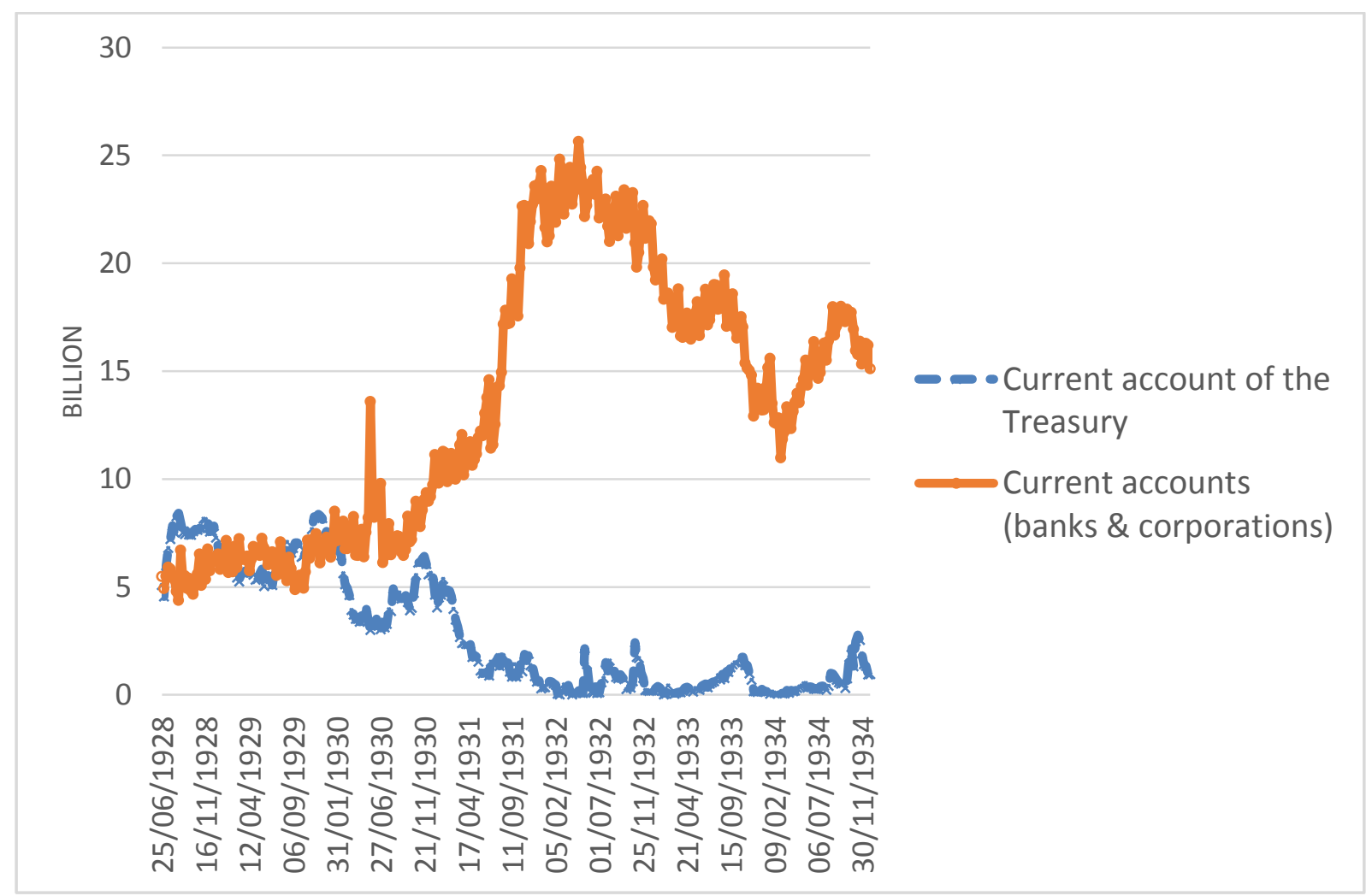

Figure 18 : current accounts at the Banque de France (1928-1934)

\section{The fall of the credit-to-money ratio}

Figure 19 shows the evolution of the ratio of total loans granted to nonfinancial corporations over total deposits in banking and nonbanking financial institutions. To compute total deposits, we summed deposits in Album banks (i.e., banking industry) and deposits in Caisses d'Epargne, Comptes postaux, and individual deposits at the Banque de France, excluding those in the four main commercial banks. 


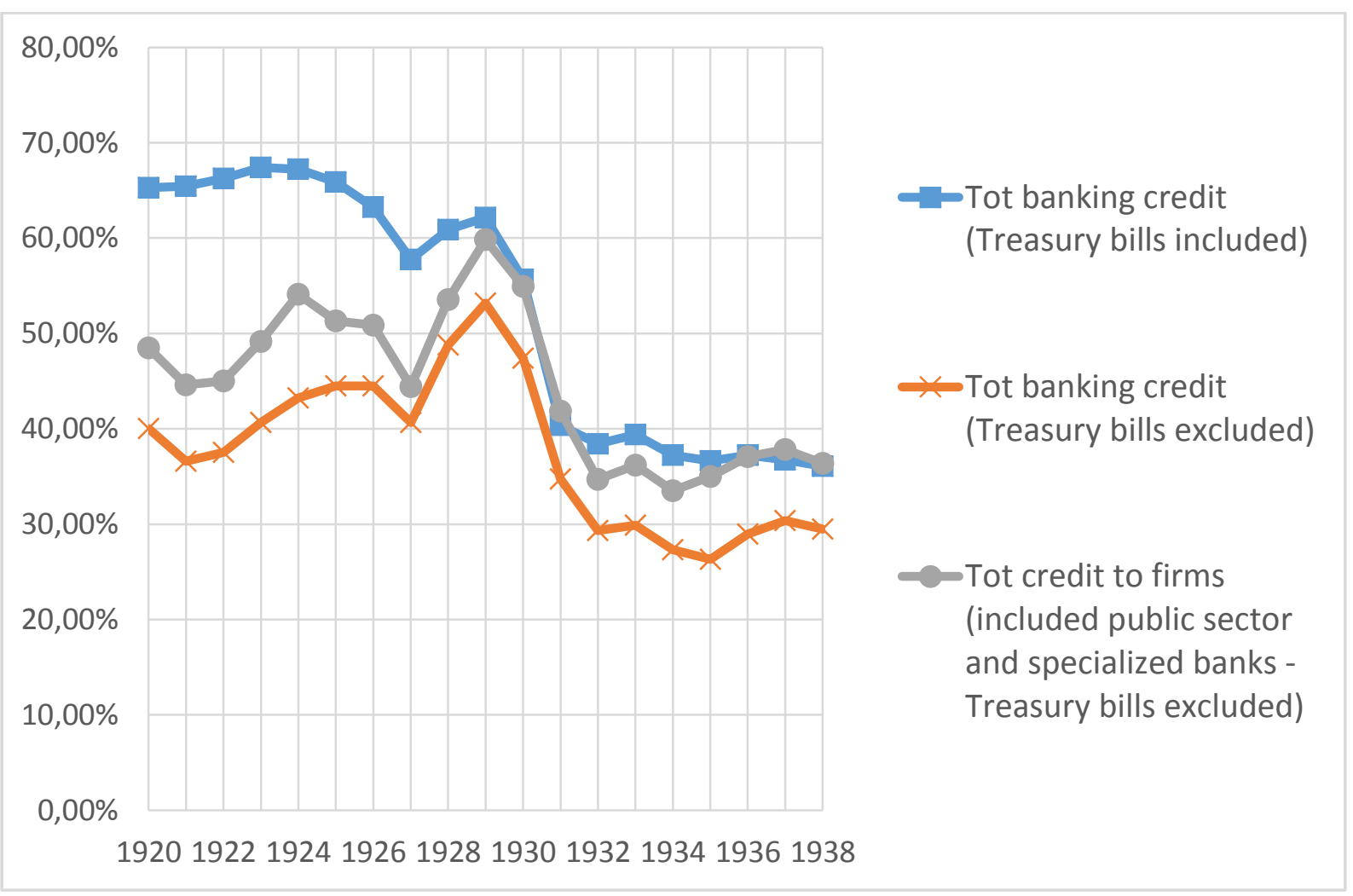

Figure 19: Credits to firms over total deposits in France

We compute three series of credit. ${ }^{36}$ The first two, the upper (blue) and lower (orange) curves in Figure 19, contain only loans granted by the banking system (i.e., overdrafts and loans backed by commercial paper and securities). The difference between the two is the exclusion, in the lower curve, of the holding of Treasury bills. Banks did not commonly distinguish commercial bills and Treasury bills in their commercial portfolios. Purchase of Treasury bills (i.e., Bons de la Défense Nationale, and later Bons du Trésor) by banks was a large-scale practice during the interwar, especially in the early 1920s (Teneul 1961).

To construct a series of credit to the economy, excluding lending to the Treasury, we follow Teneul (1961, pp. 26-28), who estimates the proportion of private versus public bills in

\footnotetext{
${ }^{36}$ Credit intermediated through notaries is missing from this estimation. Although its role declined sharply after the First World War and it then financed mainly housing and construction (Hoffman et al. 2019), it cannot be completely ruled out that some of the liquidity may have been withdrawn from banks and reinvested in business lending through notaries. Rough estimations based on Michel (1937) deal only with flows. They point out that near 1,5 billion was lent through notaries each year between 1928 and 1935 (excluding mortgage bonds issued on the market). The purpose of such loans is unknown, so we do not include them into our estimations. This amount is stable during the crisis (meanwhile, the issuance of mortgage bonds started to increase in 1929, compared to previous years). If we follow Michel (1937) and assume five-year maturity on average, the total outstanding value of such loans remains small in comparison to the 80 billion banking loans.
} 
the commercial portfolio of banks for each year. This information is unavailable in the Album and on the original balance sheets published by banks. The main sources used by Teneul (1961) are annual reports to stockholders of ten major banks (i.e., 6 deposit banks and 4 investment banks) that often presented an estimate of the breakdown between the two types of bills. Teneul added statistics published in the annual chronicles of the Revue d'Economie Politique by authors "having narrow relationships with the banking environment," and with Banque de France statistics from 1938. The third series adds loans granted by institutions other than banks. We include advances granted by the Banque de France against securities, a facility used primarily by firms rather than banks (Hautcoeur 1990, Gonjo 1996), and loans granted by Caisses de crédit Agricole, which specialized in credit to farms, Crédit National, a state-led credit institution created to finance reconstruction after the war, and private institutions specializing in medium- to long-term financing of some types of businesses, particularly UCINA and CALIF (Teneul 1961). ${ }^{37}$

The orange line in Figure 19 shows that before the crisis, approximately 53\% of total deposits in banking and nonbanking financial institutions was transferred to businesses. After the crisis, the amount was 26\%. Summing public institutions and specialized banks (grey line), the pattern does not change. These institutions did not compensate for the reduction of credit granted by the banking system, and the ratio of loans to nonfinancial corporations divided by total deposits decreased from $60 \%$ in 1929 to $33 \%$ in 1935 . The credit crunch was severe. A similar amount of deposits was financing half of the amount of credit it used to create because of the massive shift from the banking system to safe institutions that did not lend to the private economy. ${ }^{38}$ Financial intermediation in France experienced a major negative shock. No financial institution replaced the banking system as a lender to the

\footnotetext{
${ }^{37}$ The Album contains few Caisses du crédit agricole (the largest ones), but we prefer to use the aggregate national series to be as comprehensive as possible.

${ }^{38}$ Figure 26 in the Appendix shows the breakdown of the main credit series.
} 
economy. Shown in the Appendix (Figures 21 and 22), the stocks and bonds markets did not play this role either, and issues and capitalization decreased sharply after 1929.

\section{The absence of political response}

The issue of a credit crunch and the absence of adequate responses by central banks were raised by contemporaries as soon as 1931. In May 1931, Louis Rollin, Ministry of Commerce, wrote an official letter to his colleague at the Ministry of Finance to reach the Banque de France ${ }^{39}$ about the difficult access of firms to discount credits. He pointed at the Banque's balance sheet, noting, "Compared with more than 10,600 million of [francs] deposits, the discounted commercial paper payable in France reaches only FF 5 billion, down more than a billion from the average of $1930 .{ }^{, 40}$ He warned against consequences of a policy of restrictive rediscounting, fearing that the central bank's behavior was driven by overwhelming monetary principles at the expense of the real economy. The governor of the Banque de France answered two days later, a tribute to the importance of the issue, stating that the Banque was not restricting its discounts in any way. He explained, "In recent months, it [the Banque] has not ceased to discount all the presented bills, provided they offer the guarantees required by its statutes, and has not practiced at any time since beginning of the crisis, a credit restriction policy." He then explained the discrepancy between deposits and discounts at the Banque. "The deposits of a bank of issue are not-as it is for the private banks - the instrument of its discounts, but the temporarily unused amount of the monetary reserves of the market, and more especially those of the credit institutions [i..e, the large banks]." He thus explained the increase in deposits by the expectative attitude of the large commercial banks, and argued that this was not a problem because large commercial banks

\footnotetext{
${ }^{39}$ See the letter and the BoF's answer in BFA, CGM, board of directors, May $28^{\text {th }}, 1931$, p. 209.

${ }^{40}$ Our translation.
} 
did not decrease their assets. "Lastly, it is not without interest to observe that the overall amount of the portfolio of the main credit companies has remained, during the first months of this year, at very comparable figures, on the whole, with those last year." These statements show that the central bank focused on the four large commercial banks as an indicator of the health of the economy and believed strongly in the real bills doctrine, according to which a decrease in credit reflects an unavoidable decrease in real activity, a view that accords with other frequent statements made at the board of directors that emphasized that the central bank had allowed banks to fail because they had invested in bad or unsound activities that caused financial losses. ${ }^{41}$ The policy of the Banque de France during the 1930-1931 crisis has been studied elsewhere (Bouvier 1984, Hautcoeur 1990, Mouré 1991, Johnson 1998) and is not the topic of this paper. Missing from extant studies is estimation of the magnitude of the credit crunch, which the central bank could have mitigated had it increased lending to the economy.

\section{Conclusion}

Based on extensive use of newly discovered statistics, this study provides a revisionist view of the French banking system during the interwar period, especially the Great Depression. This article presents a new quantitative picture of the crisis, which leads to a complete reappraisal of the previous historiography; contrary to common wisdom, France experienced two severe and early banking crises during 1930 and 1931 that led to a credit crunch. It also analyzes transmission mechanisms of these crises. The question we address is how a series of banking panics lead to a credit crunch. A straightforward mechanism is one in which deposits are frozen by the failures of banks, and consequently, credits cannot be renewed or extended. As we have shown, however, frozen deposits represented a small portion of the decrease to total deposits. So, where did deposits go and why were they unable to finance new loans? The answer is that depositors hoarded cash and moved deposits to safe

\footnotetext{
${ }^{41}$ BFA, CGM, board of directors, December $26^{\text {th }}, 1930$, p.505.
} 
institutions (Caisse d'épargne and Banque de France) that did not invest the cash in loans in the economy. This flight-to-safety led to a credit crunch. One conclusion, which applies to the French interwar economy, is that monetary authorities and governments cannot counter such a credit crunch ex post if they are unable (or unwilling) to affect the composition of the assets of safe institutions that benefit from a flight-to-safety. The difficulty is modifying this composition without creating loss of confidence in depositors in these institutions. The flightto-safety identified in this paper, combined with findings from Mitchener and Richardson (2016) regarding the United States, sheds new light on the mechanisms of banking crises during the Great Depression, the analysis of which had up until now focused only on monetary effects (following Friedman \& Schwartz) and the cost of information asymmetries (following Bernanke).

Our approach reveals that it is necessary to investigate the entire financial sector and flows of funds, including nonbank institutions, to understand the channels through which banking panics transmit a decrease in credit to firms. Since savings institutions were common in Europe, this paper offers model for the study of other countries during the Great Depression. The French case demonstrates that some minor macroeconomic assumptions and extrapolations on monetary statistics can be misleading and introduce large, persistent biases in historiography. Such historiographical biases, driven by the availability of archives, is not politically neutral, as demonstrated by the long influence of the powerful narrative built by large, resilient banks and the Banque de France, according to which the banking troubles of the early 1930s had not been detrimental to the French economy.

Extant research discusses the gold standard mentalité, or "gold illusion," of the Banque de France, and its consequences in the world economy (Mouré 1991, Eichengreen 1992, Johnson 1998, Eichengreen and Temin 2000), but they miss the domestic side of this story. The current paper shows that this policy occurred at the same time as a series of major 
banking panics that led to a massive credit crunch in the French economy. Although the central bank did not have a statistical apparatus to assess the extent of this credit crunch, its inability to fix the credit system is explained by a focus on real bills (i.e., discount) and a lack of macroeconomic perspectives on the financial system. Our interpretation of the banking crisis is more consistent with what is known about the evolution of the French real economy during the Great Depression. In comparison to other countries, France experienced a delayed but more prolonged and deep crisis (Figure 23, Appendix). The industrial production index began to fall in autumn 1930 rather than in $1929,{ }^{42}$ but it never recovered its pre-1929 level (Sauvy 1984, Eichengreen 1992, Romer 1993). The previous narrative gave no role to finance and domestic banking problems during this process. Contrarily, we show that the banking panic and a sharp drop in credit occurred at the same time as the real economy entered a crisis. The transmission mechanism we identify, with a sharp, persistent drop in the credit-todeposit ratio, accords with the absence of recovery during the 1930s. The 1930-1931 crisis caused persistent damage to financial intermediation. Hence, results encourage new investigations into the link between the financial crisis and the real economy during the Great Depression in France and throughout Europe.

\footnotetext{
${ }^{42}$ Based on another set of indicators, Marseille (1980) argued contrary to the common view that the crisis started earlier. A full assessment of Marseille's claims is left for further discussions.
} 


\section{References}

Accominotti, O. (2009). The sterling trap: foreign reserves management at the Bank of France, 1928-1936. European Review of Economic History, 13(3), 349-376.

Andrieu, C. (1991). La banque sous l'occupation: Paradoxes de l'histoire d'une profession. Presses de Sciences Po.

Baele, L., Bekaert, G., Inghelbrecht, K., \& Wei, M. (2013). Flights to safety (No. w19095). National Bureau of Economic Research.

Baubeau, P. (2004). Les" cathédrales de papier" ou la foi dans le crédit: naissance et subversion du système de l'escompte en France: fin XVIIIe-premier XXe siècle (Doctoral dissertation, Paris 10).

Baubeau, P. (2011). Gaston Roulleau et l'étude des effets de commerce ou la tension entre statistiques fiduciaires et conceptions métallistes. Histoire \& mesure, 26(XXVI-1), 221242.

Baubeau, P. (2018). The Bank of France's balance sheets database, 1840-1998: an introduction to 158 years of central banking. Financial History Review, 25(2), 203-230.

Bernanke, B. S. (1983). Nonmonetary Effects of the Financial Crisis in the Propagation of the Great Depression. The American Economic Review, 73(3), 257-276.

Bernanke, B., \& James, H. (1991). The gold standard, deflation, and financial crisis in the Great Depression: An international comparison. In Financial markets and financial crises (pp. 33-68). University of Chicago Press.

Bonin, H. (1999). "Les Caisses d'épargne françaises (1914-1945)" in L'histoire des Caisses d'épargne européennes, tome 4, Les éditions de l'épargne.

Bonin, H. (2000). Les banques françaises de l'entre-deux-guerres (1919-1935) (Vol. 3). Plage.

Bonin, H. (2002). La Banque nationale de crédit. Histoire de la quatrième banque de dépôts française en 1913-1932, Plage.

Bonin, H. (2014). Banque et identité commerciale. La Société générale (1864-2014). Presses Univ. Septentrion.

Bouvier, J. (1984). The French Banks, Inflation and the Economic Crisis, 19191939. Journal of European Economic History, 13(2), 29-80.

Bozio, A. (2002). La capitalisation boursière en France au XXe siècle. Masters' Thesis. Paris School of Economics. 
Bridji, S. (2013). The French Great Depression: A business cycle accounting analysis. Explorations in Economic History, 50(3), 427-445.

Caballero, R. J., \& Krishnamurthy, A. (2008). Collective risk management in a flight to quality episode. The Journal of Finance, 63(5), 2195-22

Christen-Lécuyer, C. (2004). Histoire sociale et culturelle des caisses d'épargne en France: 1818-1881. Economica.

Coupry, H. (1935). Contribution à l'histoire des caisses d'épargne ordinaires en France. Imprimerie Moderne-A. Destout.

Delaporte, R. (1924). La Banque. Ses opérations. Son organisation. Son exploitation, aux points de vue juridique, administratif et comptable, Impr. des établissements A. Brulliard.

Desjardins, B., Lescure, M., Nougaret, R., Plessis, A., \& Straus A. ed. (2003). Le Crédit lyonnais, 1863-1986: études historiques, Paris, Librairie Droz.

Duchaussoy, V. \& Monnet, E. (2015). La Banque de France et le financement du Trésor pendant la Première Guerre mondiale, in La mobilisation financière pendant la Grande Guerre, F. Descamps et L.Quennouëlle-Corre (dir.), Paris, CHEFF, , 121-152.

Eichengreen, B. (1992). Golden fetters, Oxford University Press.

Eichengreen B. (2004). Understanding the Great Depression, The Canadian Journal of Economics, Vol. 37, No. 1 (Feb., 2004), pp. 1-27

Eichengreen, B., \& Temin, P. (2000). The gold standard and the great depression. Contemporary European History, 9(2), 183-207.

Feinstein, C. H., Temin, P., \& Toniolo, G. (1995). International economic organization: Banking, finance, and trade in Europe between the wars. Banking, currency, and finance in Europe between the wars, 9-76.

Ferguson, T., \& Temin, P. (2004). Comment on "The German Twin Crisis of 1931”. The Journal of Economic History, 64(3), 872-876.

Friedman, M., \& Schwartz, A. J. (1963). A monetary history of the United States, 18671960. Princeton University Press.

Flandreau Marc., \& Frédéric, Z. (2009). Development Centre Studies The Making of Global Finance 1880-1913. OECD Publishing.

François-Marsal, F. ed. (1929), Encyclopédie de Banque et de Bourse. Paris, Imprimerie Crété.

Fratianni, Michele, and Federico Giri (2017). "The tale of two great crises." Journal of Economic Dynamics and Control 81: 5-31. 
Gonjo, Y. (1996), La modernisation de la Banque de France (1930-1946), Études et documents, VIII, p. 281-356.

Grossman, R. S. (1994). The shoe that didn't drop: explaining banking stability during the Great Depression. The Journal of Economic History, 54(3), 654-682.

Hautcœur, P. C. (1990). La Banque de France et la crise bancaire de 1930-32. Études et documents, 2, 295-315.

Hautcoeur, P. C. (1994). Le marché boursier et le financement des entreprises françaises (1890-1939) (Doctoral dissertation, Université de Paris I: Panthéon-Sorbonne)

Hautcoeur, P. C., Riva, A., \& White, E. N. (2014). Floating a "lifeboat": The Banque de France and the crisis of 1889. Journal of Monetary Economics, 65, 104-119.

Hamilton, J. D. (1988). Role of the International Gold Standard in Propagating the Great Depression. Contemporary Economic Policy, 6(2), 67-89.

Hoffman, P. T., Postel-Vinay, G., \& Rosenthal, J. L. (2000). Priceless markets: the political economy of credit in Paris, 1660-1870. University of Chicago Press.

Hoffman, P. T., Postel-Vinay, G., \& Rosenthal, J. L. (2019). Dark Matter Credit The Development of Peer-to-Peer Lending and Banking in France, Princeton University Press.

Irwin, D. A. (2010). “Did France Cause the Great Depression?” (No. w16350). National Bureau of Economic Research.

James, H. (2009). The Creation and Destruction of Value. Harvard University Press.

Johnson, H. C. (1998). Gold, France, and the Great Depression, 1919-1932. Yale

University Press.

Jonker, J., \& Van Zanden, J. L. (1995). Method in the madness? Banking crises between the wars, an international comparison. Banking, Currency, and Finance in Europe between the Wars, 77-93.

Kaufmann, E. (1914). La banque en France. M. Giard \& É. Brière.

Kindleberger, C. P. (1986). The World in Depression, 1929-1939: Revised and enlarged edition (Vol. 4). Univ of California Press.

Krishnamurthy, A. (2010). Amplification mechanisms in liquidity crises. American Economic Journal: Macroeconomics, 2(3), 1-30.

Lacoue-Labarthe, D. (2005). La France a-t-elle connu des paniques bancaires inefficientes?. Revue d'économie politique, 115(5), 633-656.

Laufenburger, H. (1940), Les banques françaises ; enquête sur les changements de structure du crédit et de la banque, Fondation Rockefeller, Paris, Sirey. 
Lescure, M., (1999) «Small and Medium-size Industrial Enterprises in France, 19001975”, in M. Sawaï (ed), Large Concerns, Small Firms, Oxford, Oxford University Press, p. $140-167$.

Lescure M. (1996), PME et croissance économique : l'expérience française des années 1920, Paris, Economica.

Lescure, M. (2003). Le Crédit lyonnais et l'immobilier au XIXe siècle: la société foncière lyonnaise (1879-1913). In Le Crédit lyonnais (1863-1986) (pp. 367-383). Librairie Droz.

Lescure, M. (2004), "La crise bancaire des années 1930: la crise des banques locales et régionales en France?” in Banques locales et banques régionales en Europe au XXe siècle, Paris, Albin Michel.

Lescure, M. (2016), "1914-1918, les débuts du « great reversal » des banque françaises", in F.Cardoni, Les banques françaises et la Grande Guerre, Paris : IGPDE, p. 209227

Levy-Garboua, V., \& Monnet, É. (2016). Les taux d'intérêt en France: une perspective historique. Revue d'économie financière, (1), 35-58.

Lévy-Leboyer, M. (1995), Préface, in Lévy-Leboyer, M. (dir.) Les banques en Europe de l'Ouest de 1920 à nos jours, Paris, Comité pour l'histoire économique \& financière de la France, I-XV.

Marseille, J. (1980). Les origines" inopportunes" de la crise de 1929 en France. Revue économique, 648-684.

Meltzer, A. H. (2003). A History of the Federal Reserve, 1913-1951, Vol. 1, Chicago University Press.

Michel, E. (1937). Fortune privée immobilière 1936 et dette hypothécaire (1935). Journal de la société française de statistique, 78, 321-333.

Mitchell, B. (Ed.). (1998). International historical statistics: Europe 1750-1993. Springer.

Mitchener, K. J., \& Richardson, G. (2016). Network contagion and interbank amplification during the Great Depression (No. w22074). National Bureau of Economic Research.

Monnet, E. (2018), Controlling Credit. Central Banking and the Planned Economy in Postwar France, 1948-1973, Cambridge University Press. 
Mouré, K. (1991). Managing the Franc Poincaré: economic understanding and political constraint in French monetary policy, 1928-1936. Cambridge University Press.

Nurkse, R. (1944). International currency experience: lessons of the interwar period (No. 4). League of Nations.

Patat, J. P., \& Lutfalla, M. (1986). Histoire monétaire de la France au XXe siècle. Economica.

Piketty, T. (2001). Les hauts revenus en France au XXe siècle. Hachette.

Plessis, A. (1991). Les banques, le crédit et l'économie. Entre l'Etat et le marché, Galimard, 331-364.

Plessis, A. (1996). Les banques françaises dans les grandes crises du 20e siècle. Vingtieme siecle. Revue d'histoire, 85-93.

Praquin, N. (2005). "La comptabilité aux frontières de l'organisation: un instrument de la stratégie entrepreneuriale. Le cas du Crédit Lyonnais sous Henri Germain (1864-1905)." Entreprises et histoire 2: 45-58.

Praquin, N. (2007). L'analyse du risque bancaire au Crédit Lyonnais (1880-1925). Entreprises et histoire, (3), 56-72.

Praquin, N. (2010). "The Crédit Lyonnais in France (c. 1871-1918): Using cash flow analysis to assess risk in banking." Accounting Historians Journal 37.1: 1-28.

Rajan, R. G., \& Zingales, L. (2003). The great reversals: the politics of financial development in the twentieth century. Journal of financial economics, 69(1), 5-50.

Reinhart, C. M., \& Rogoff, K. S. (2009). This time is different: Eight centuries of financial folly. princeton university press.

Romer, C. D. (1993). The nation in depression. Journal of Economic Perspectives, 7(2), 19-39.

Saint Marc, M. (1983). Histoire montétaire de la France: 1800-1980. Presses Universitaires de France-PUF.

Sauvy, A. (1984). Histoire économique de la France entre les deux guerres. Paris: Presses Univ. de France (revised edition).

Schnabel, I. (2004). The German twin crisis of 1931. The Journal of Economic History, 64(3), 822-871.

Schularick, M., \& Taylor, A. M. (2012). Credit booms gone bust: Monetary policy, leverage cycles, and financial crises, 1870-2008. American Economic Review, 102(2), 102961. 
Seguin, M. (1938). L'évolution des banques régionales en France de 1918 à 1938. Société d'études et d'informations économiques.

Sicsic, P. (1993). The Inflow of Gold to France from 1928 to 1934. Banque de France.

Straus, A. (2004), ' 'La politique des banques régionales dans l'entre-deux-guerres', in M. Lescure (ed) Banques locales et banques régionales en Europe au XXe siècle, Paris, Albin Michel.

Teneul, G.F (1961) Le financement des entreprises en France: depuis la fin du XIXe siècle à nos jours. Librairie geńérale de droit et de jurisprudence.

Temin, P. (2008). The German crisis of 1931: evidence and tradition. Cliometrica, 2(1), $5-17$.

Ungaro, S. (2018). (How) Do Central Clearing Parties Reduce Risk on Repo Markets? Working paper, Paris School of Economics.

Villa, P. (1994). Un siècle de données macroéconomiques. Paris, INSEE. 


\section{APPENDIX}

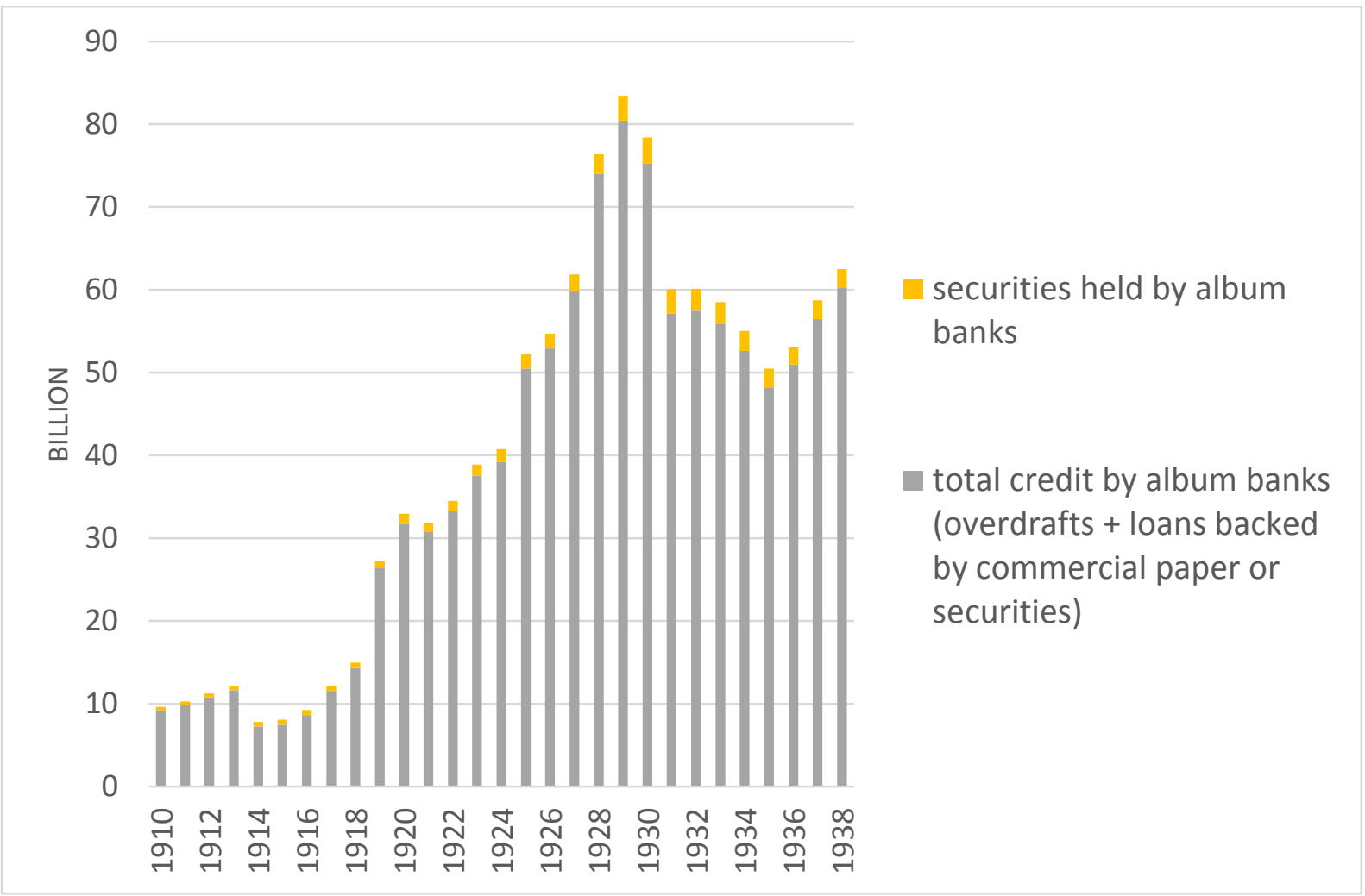

Figure 20: Securities held in banks portfolio, 1910-1938.

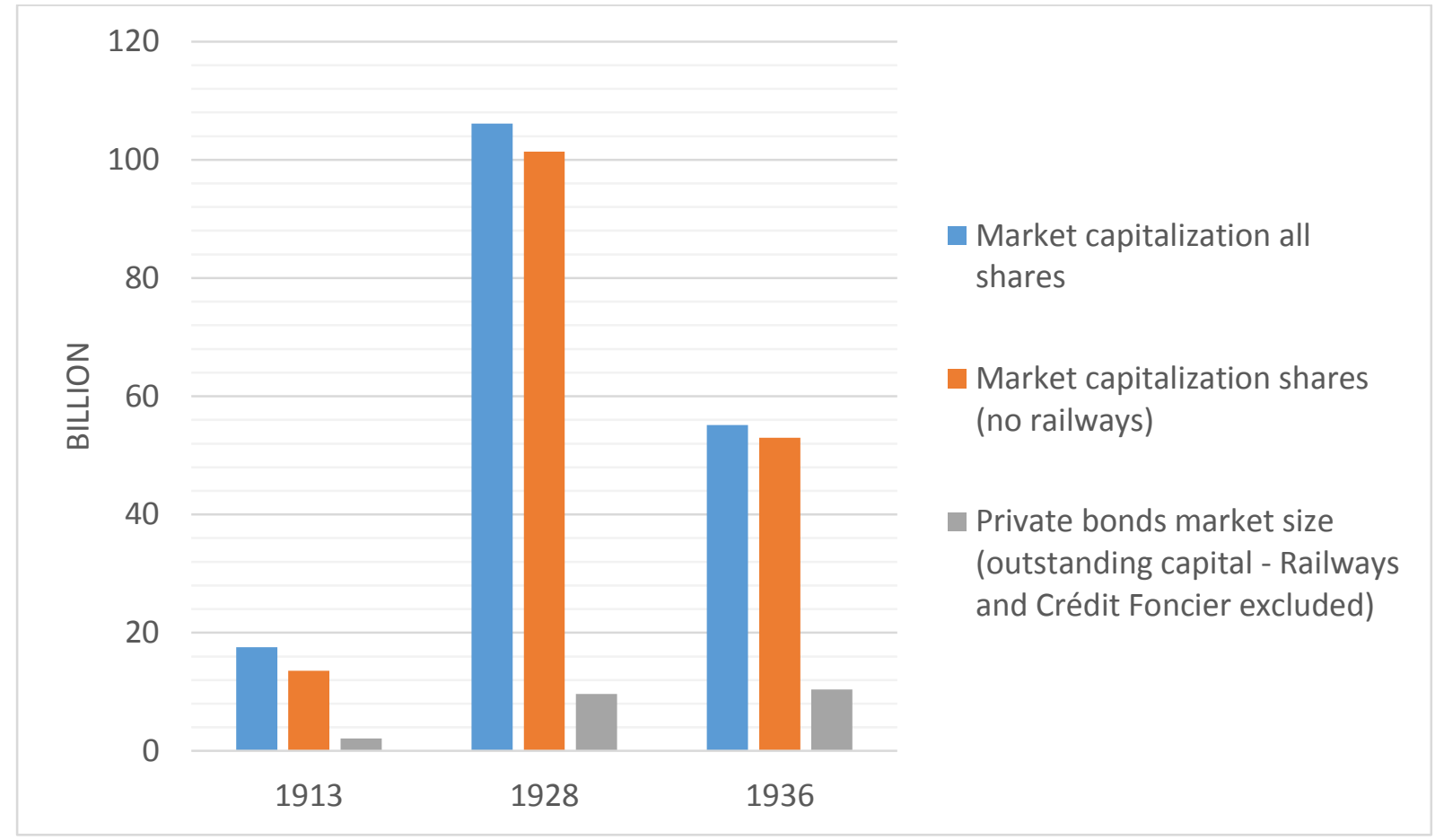

Figure 21 : Shares and bonds on Paris Stock Exchange 


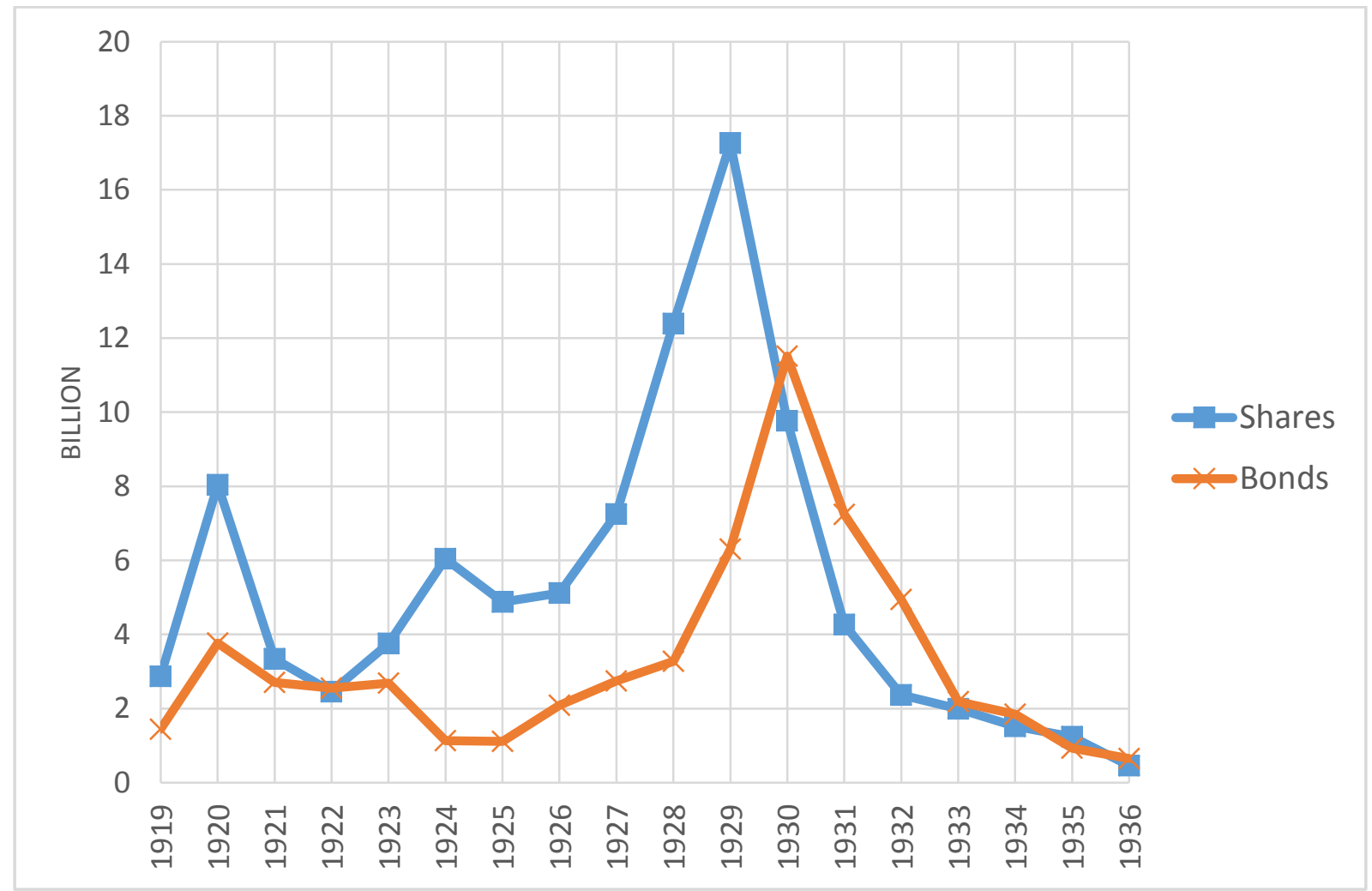

Figure 22 : Issues of shares and bonds on the Paris stock exchange, 1919-1936

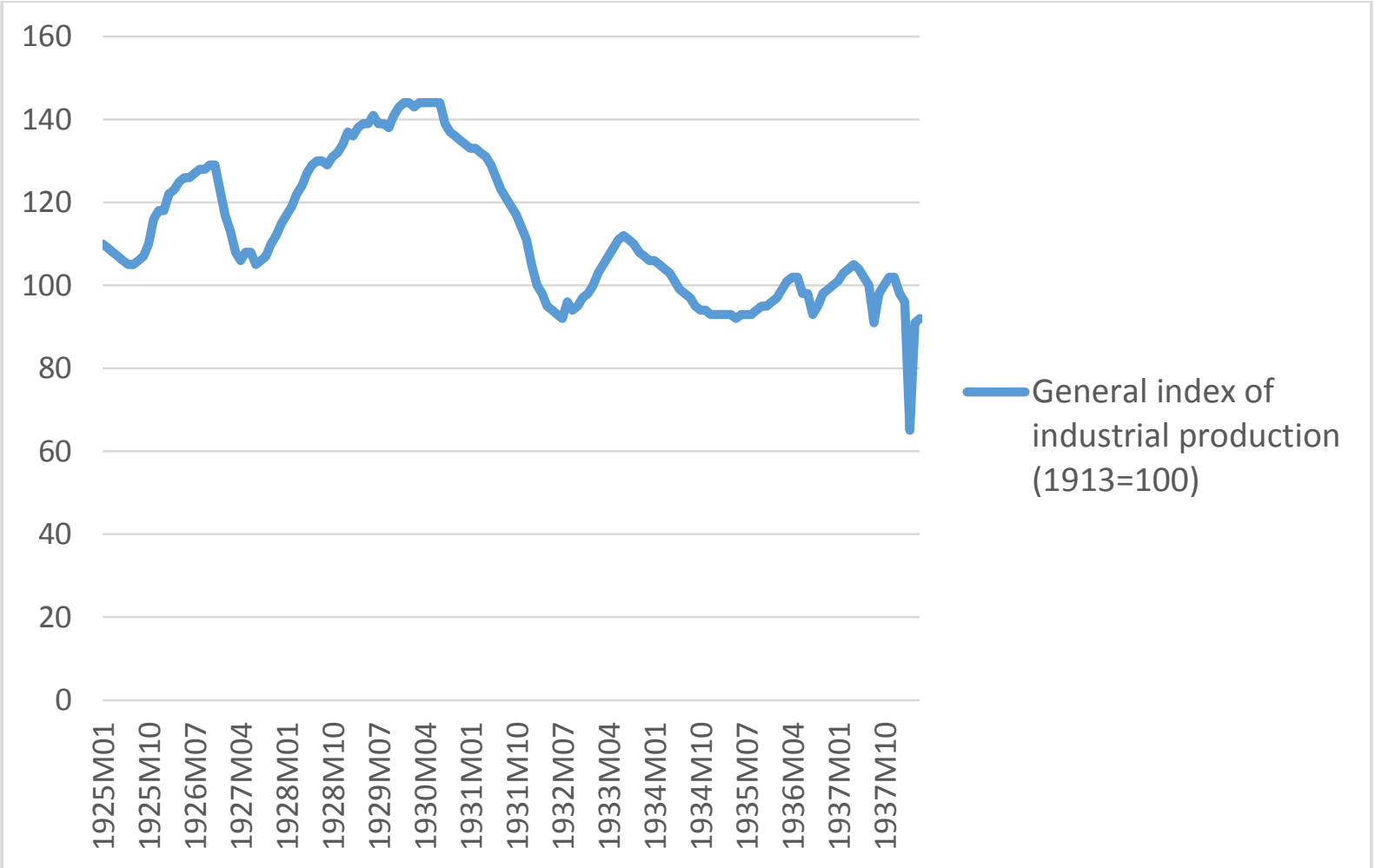

Figure 23 - General index of industrial production $(1913=100)$ 


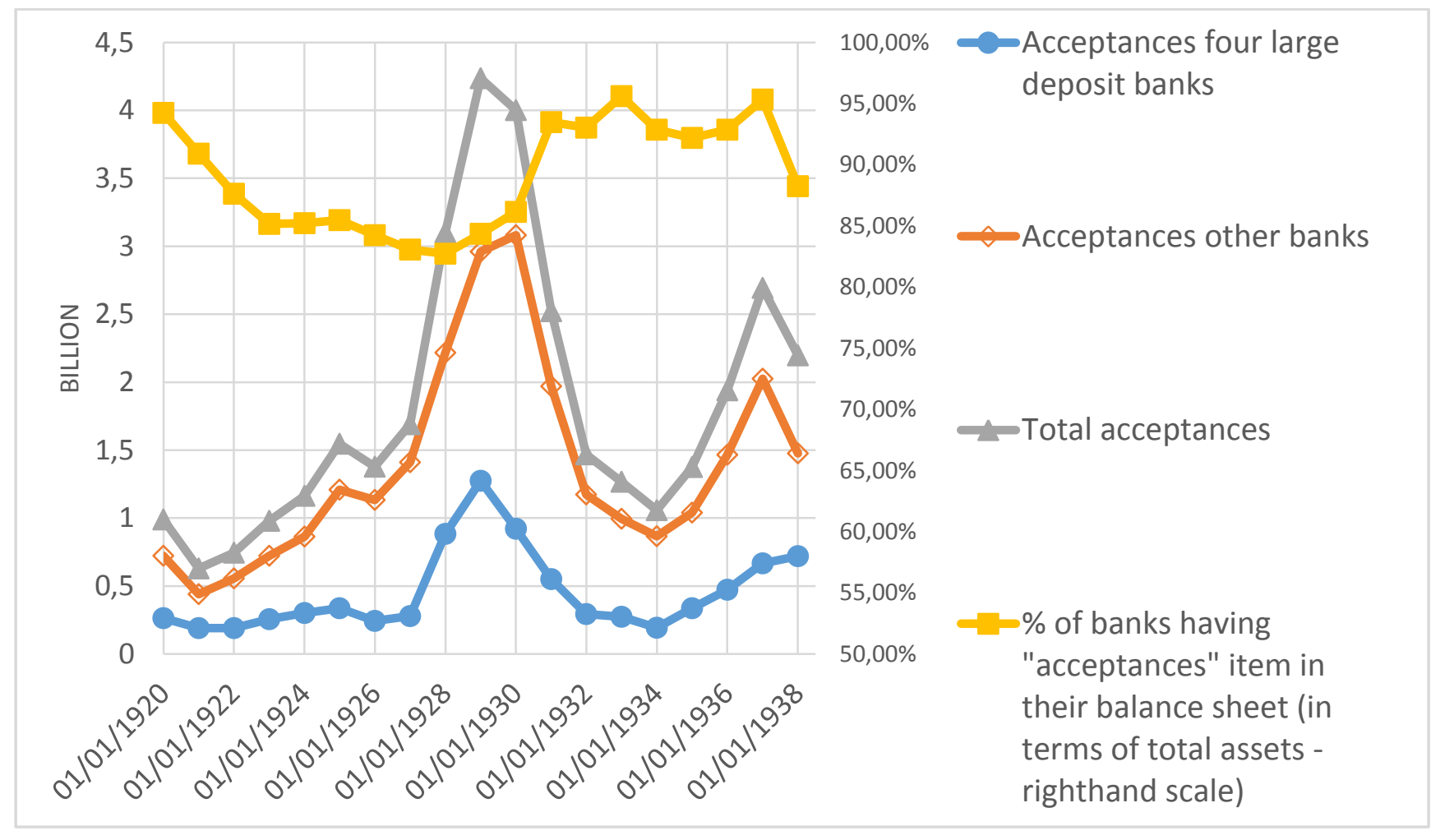

Figure 24 : Acceptances in the balance sheets of banks

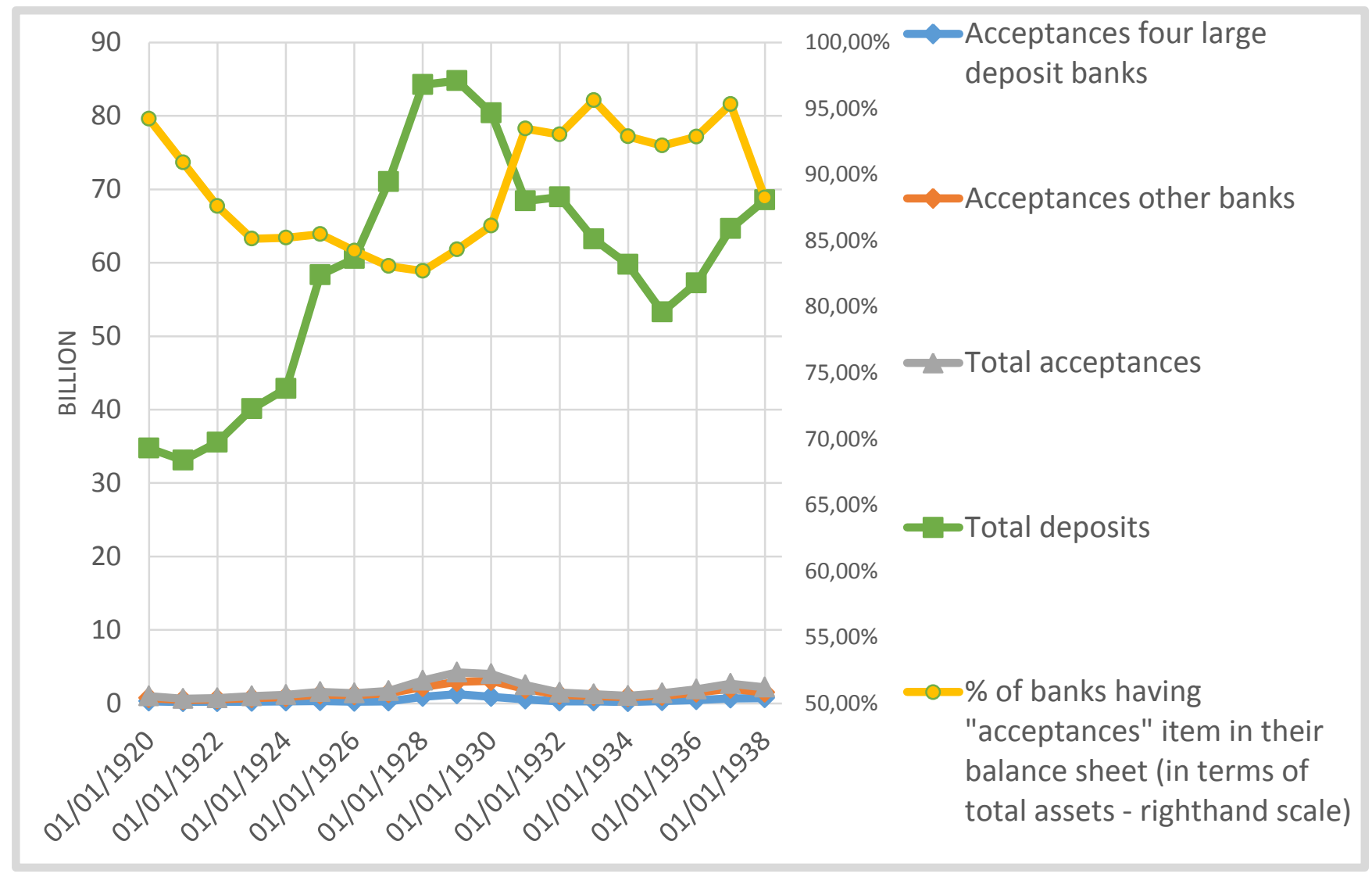

Figure 25 : Acceptances and deposits in the balance sheets of banks 


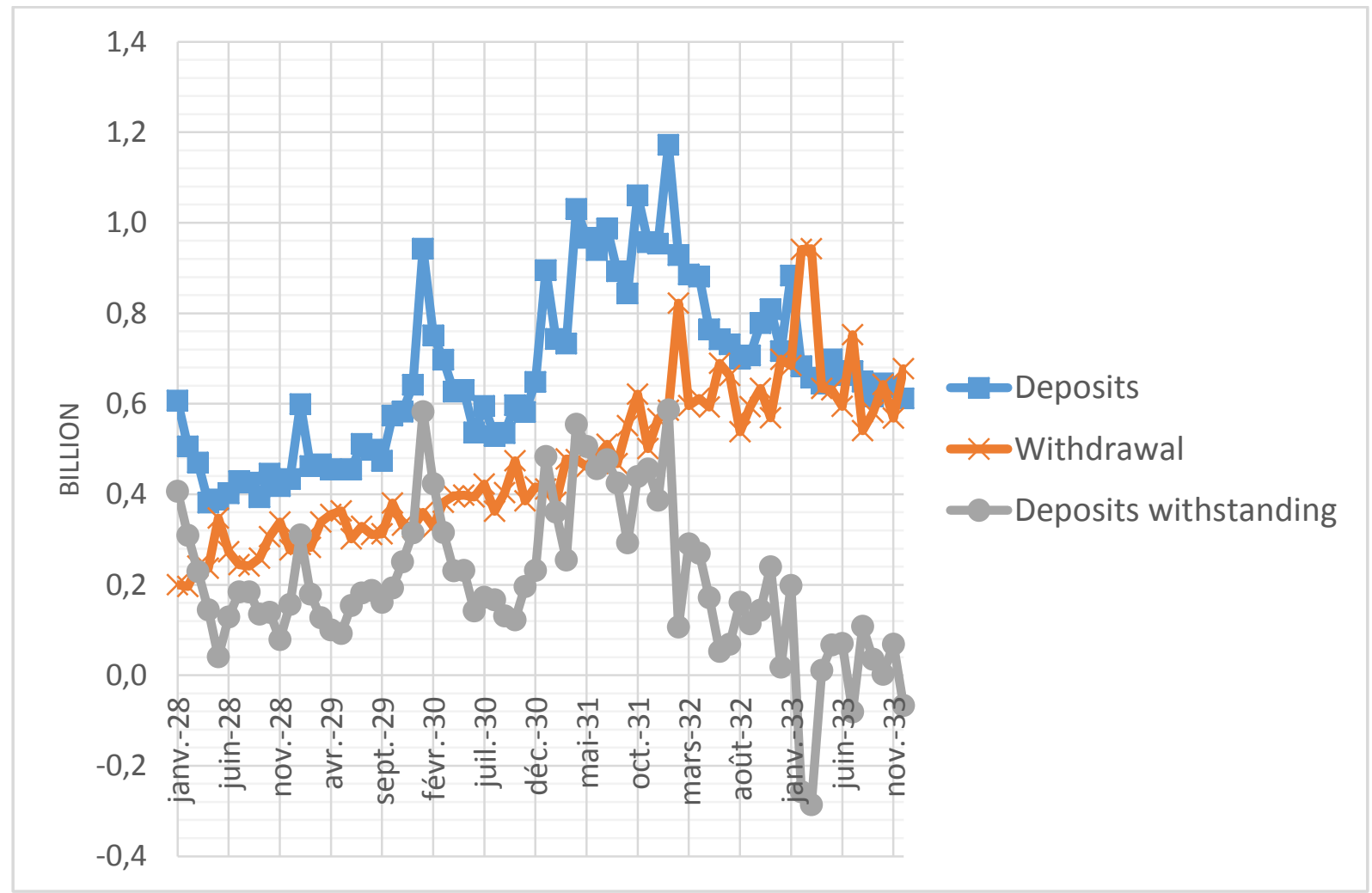

Figure 26 - Monthly deposits and withdrawals at the Caisse Nationale d'Epargne

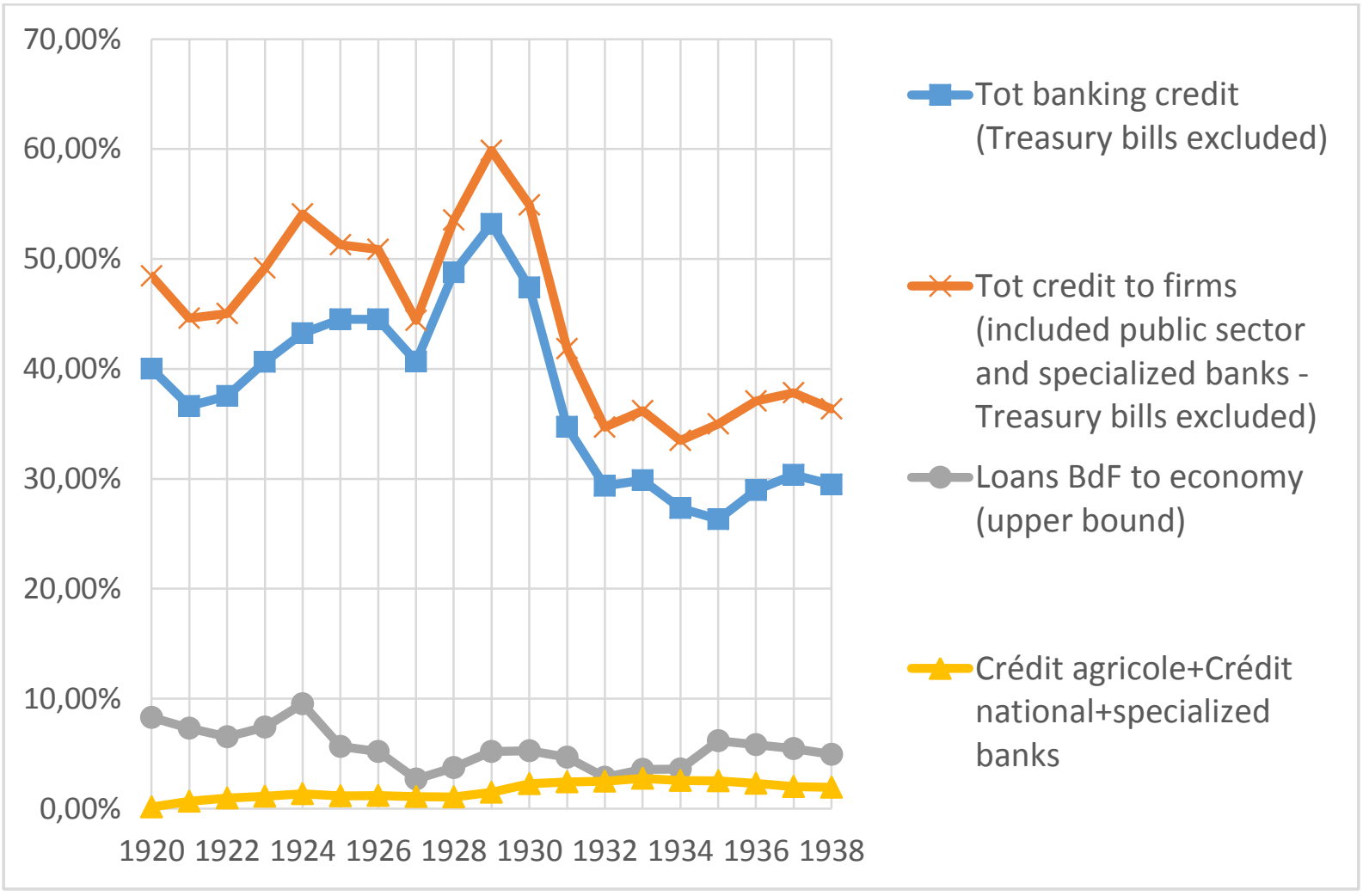

Figure 27 - Credit on total deposits, 1920-1938 


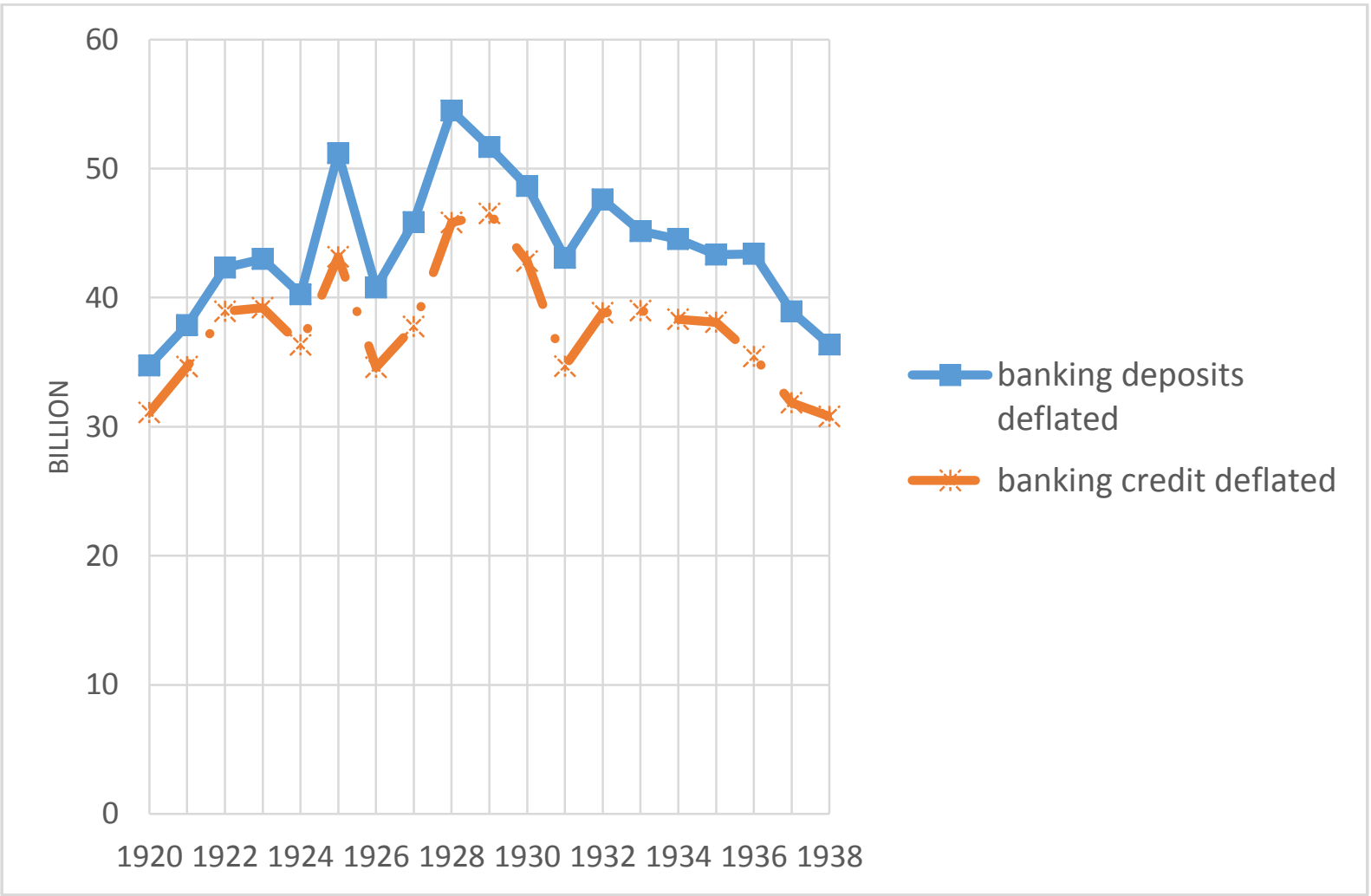

Figure 28 : Banking credit and deposits, deflated series

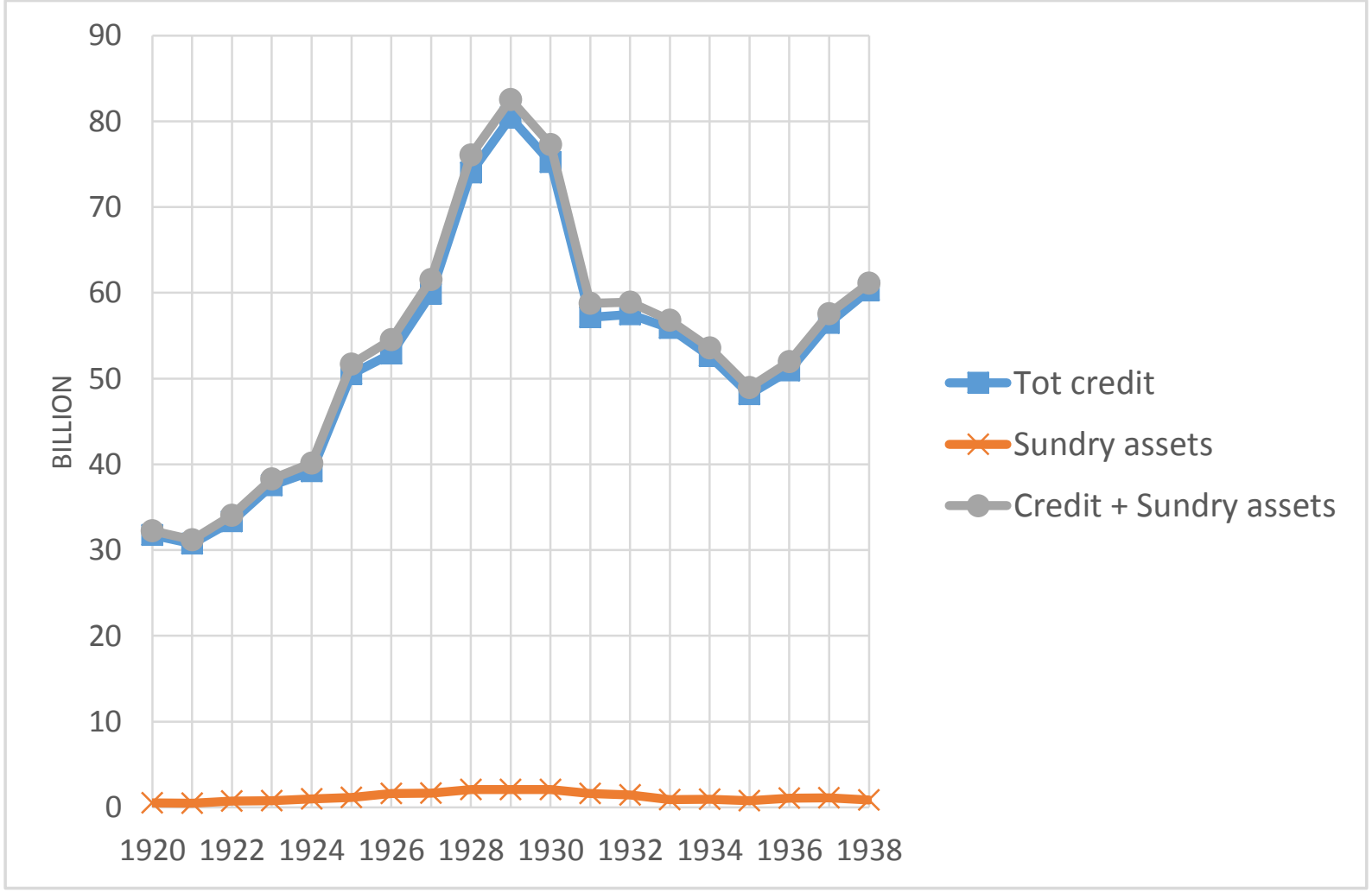

Figure 29 : Sundry assets in the balance sheets of banks 


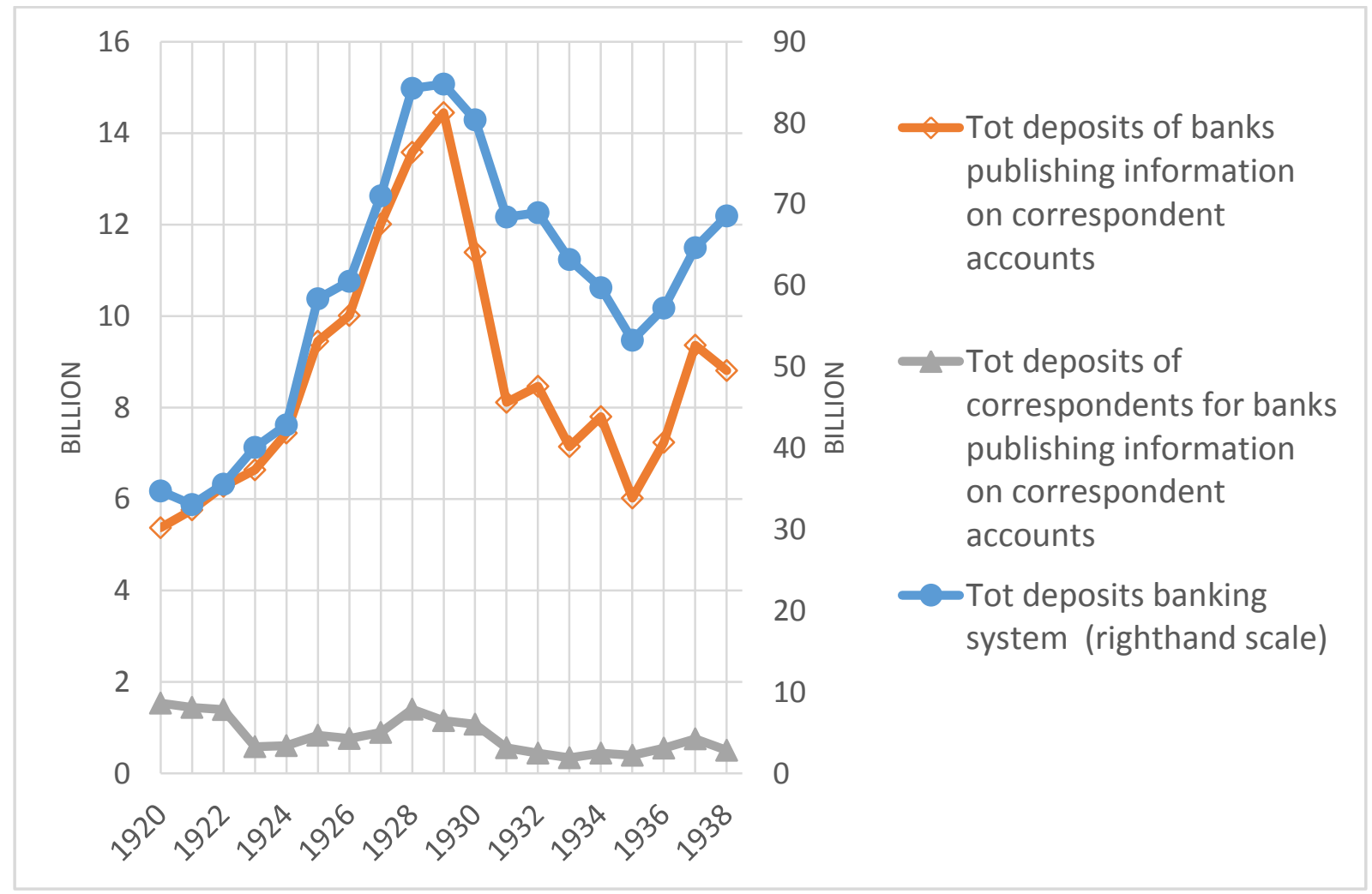

Figure 30 : Deposits of correspondents in the balance sheets of banks 